\title{
جهود إسماعيل الفاروقي في علم تاريخ الأديان
}

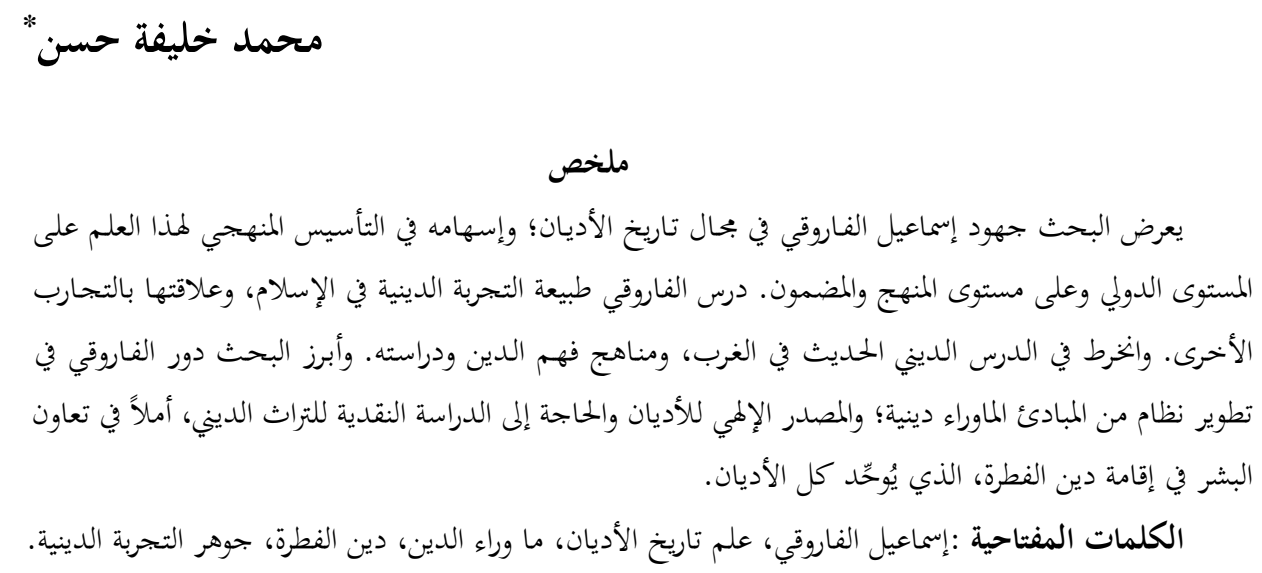

\section{Abstract \\ Efforts of Ismail al-Faruqi in the Field of History of Religions Muhammad Khalifah Hassan}

This paper presents the efforts of Ismail al-Faruqi in the field of history of religions and his contributions in the methodological establishment of this field on the international level, particularly in the areas of methodology and content. Al-Faruqi studied the nature of the religious experience in Islam, and its relationship with other experiences. He engaged in the modern religious studies in the West, and the methods of understanding and studying religion. The paper highlights Al-Faruqi's role in developing a system of Meta-Religious principles, the divine source of religions, and the need for critical assessment of religious heritage, in the hope that human beings would cooperate to establish the religion of Fitra (natural disposition), which unites all religions.

Keywords: Ismail al-Faruqi, History of Religions, Meta-Religion, Religion of Fitra (Natural Disposition), Essence of Religious Experience.

$$
\begin{aligned}
& \text { * دكتوراه في تاريخ الأديان من جامعة تمبل بالولايات المتحدة الأمريكية، أستاذ مقارنة الأديان ومدير مركز القرضاوي }
\end{aligned}
$$

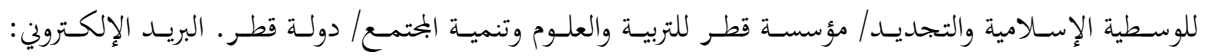

$$
\begin{aligned}
& \text { mohamedkhalifa@hotmail.com }
\end{aligned}
$$

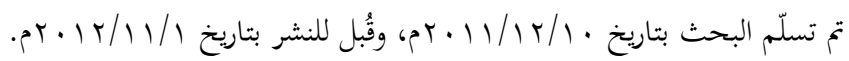


علم الأديان علم إسلامي أصيل له جذوره في القرآن الكريم وفي التراث الإسلامي.

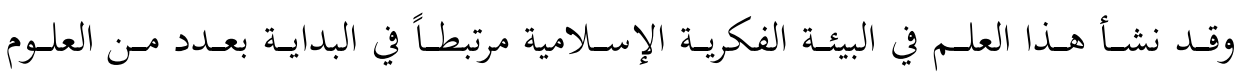

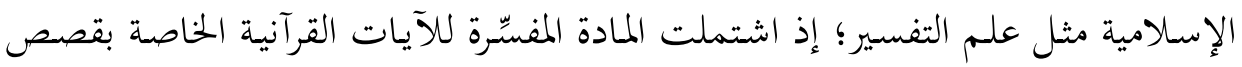

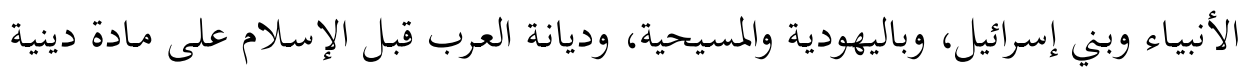

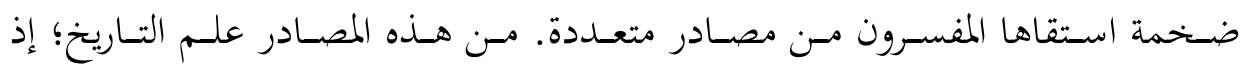

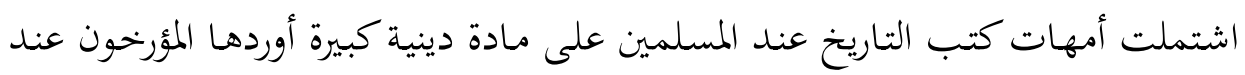

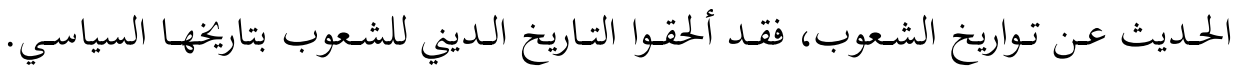

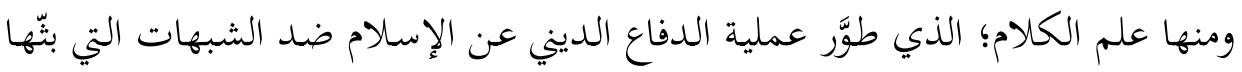

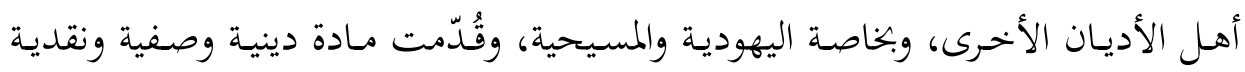

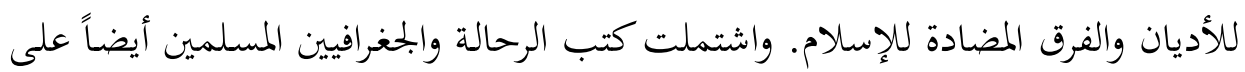

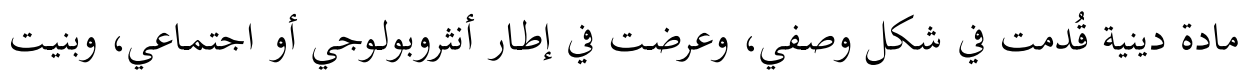

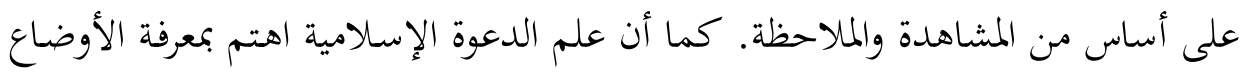

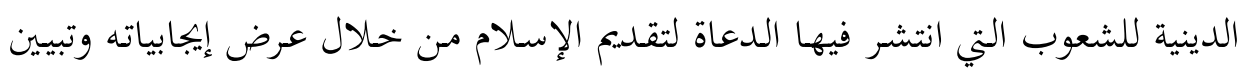

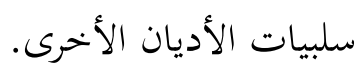

وفي مرحلة تالية استقل علم الأديان عن العلوم الإسلامية الأخرى التي ارتبط بها،

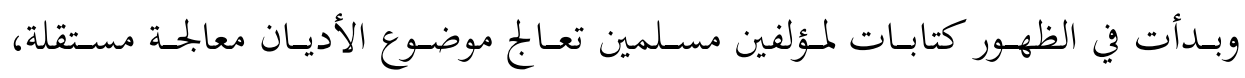

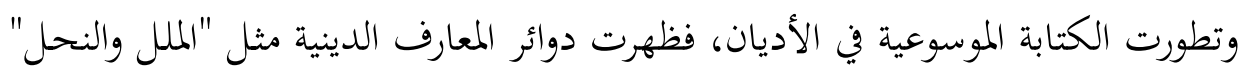

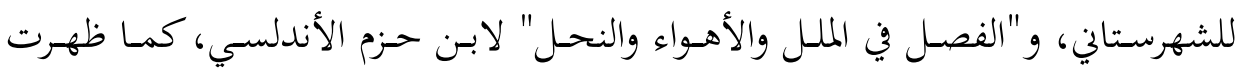

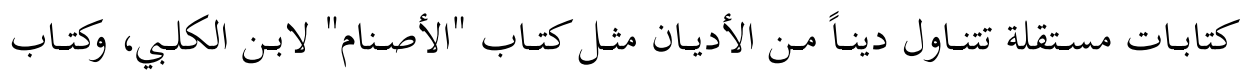

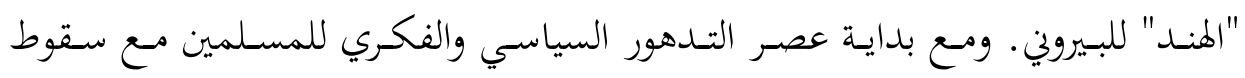

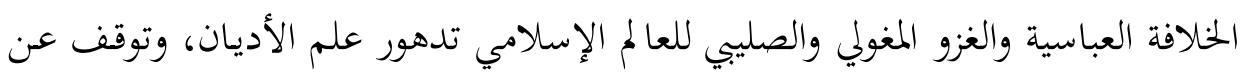

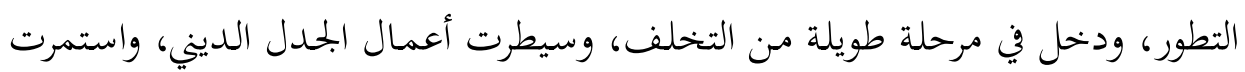
هذه الأوضاع حتى القرن العشرين. 
وفي العصـر الحـديث انتقـل علـم الأديـان إلى الغـرب، وشههد مرحلة ازدهـاره خهلال القرنين التاسع عشر والعشرين، لظروف مرتبطة بانتشار الاستعمار الغربي في معظم بلدان العالم، وبتطور العلوم الاجتماعية والإنسانية في الغرب خلال القرنين المذكورين. وفي العالم الإسلامي ظهر علماء قليلون اهتمـوا بعلم تـاريخ الأديان، وعملوا على

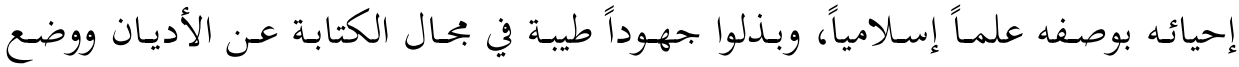

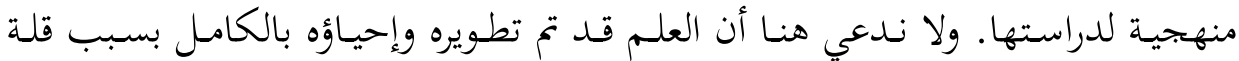
العلماء المسلمين المهتمين به، ولا تزال الجهود مطلوبة لإتمام إحياء هذا العلم المهم. ومسن بين العلماء المسلمين القليلين الذين اهتموا بتاريخ الأديان في القرن العشرين،

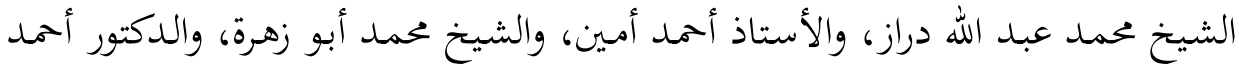

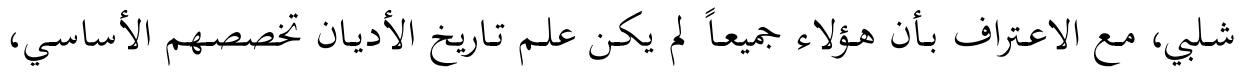
ولكنهم تناولوه على هامش تخصصاقم.

وهنـا تـبرز شخصسية الـدكتور إسماعيـل الفـاروقي في بحـال تـاريخ الأديـان؛ إذ تمثـل الشخصية الأساسية في بجـال إحيـاء هـذا العلم على المستوى المنهجي، وعلى مستوى الموضوع، ويمكننا بذلك النظر إلى الفـاروقي على أنه مؤسس علم تاريخ الأديان الحمديث

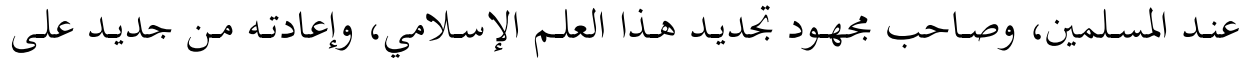
خارطة العلوم عند المسـلمين. وقد أتت مسـاهمة الفـاروقي في هـذا البحال على مستويين

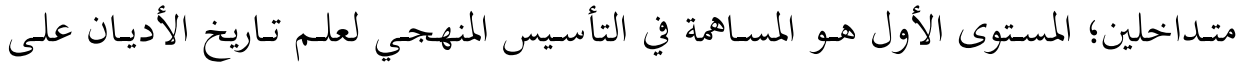
المستوى العلمي الدولي؛ أمـا المستوى الثاني فهو يتمثل في المساهمة في إحياء علم تاريخ الأديان عند المسلمين على مستوى المنهج والمضمون.

لقـد انخرط الفـاروقي في عملية التأسيس المنهجي لعلم تاريخ الأديان على المستوى

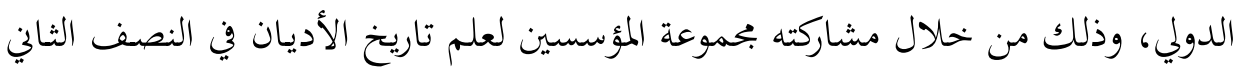
مـن القـرن العشـرين. وقـــ تـولى إسماعيـل الفـاروقي رئاسـة المحسور الخـاص بالإسـالام في الجمعيـات العلميـة المتخصصـة، مثـل جمعيـة تـاريخ الأديـان بجامعـة شيكاغو، التي كـان يرأسها مؤرخ الأديان الشهير مرسيا إلياده، وكذلك أكاديمية الدراسة العلمية للدين. وقد 
شـارك في أعمال هـاتين الجمعيتـين العلميتـين مشـاركة كاملة جهادة مـن خهلال الأبجاث لهاث المنهجية، والإشراف على محور الإسلام في المؤتمرات، والندوات، والدوريات الخاصة بتاريخ

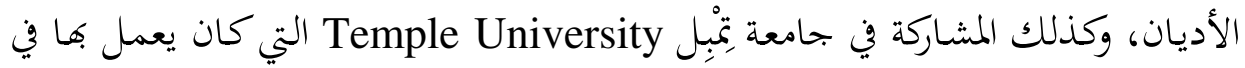
تنمية علم تاريخ الأديان، وفي التدريس والإشراف على عدد من الطلاب المسلمين وغير المسلمين. ومن أبرز طلابه غير المسلمين الدكتور جون اسبوزيتو، والدكتور جيمس زغبي ونبي. أمـا طلابـه المسـلمون فقد أسس مسن خلالهـم مدرسـة إسلامية جديدة في تاريخ الأديـان أحيا بهم العلم الإسلامي القلديم في هذا المحال.

وقد شـارك الفـاروقي عـدداً مـن أهـم علمـاء تاريخ الأديان في القرن العشرين، وذلك بالتــأليف المشـترك، والمـؤتمرات، والنــدوات المشـتركة، والعضــوية المشــتركة في الجمعيـات العلميـة. ونـذكر مـن هـؤلاء: مرسيا إلياده، وجوزيـف كيتاجـاوا، وولفـرد كانتويـل سميـث، وليونارد سودلر، وتشارلز لونج، وتشارلز آدمز، وسوفير، ويواكيم فاخ. وخلال فترة عمله في جامعة تمبل في مدينة فيلادلفيا أسهم الفـاروقي في تحويل قسم الدين إلى مركز لتاريخ الأديان، وقد كان الفاروقي مؤهلاً لأن يقوم بهذا الدور للأسباب الآتية:

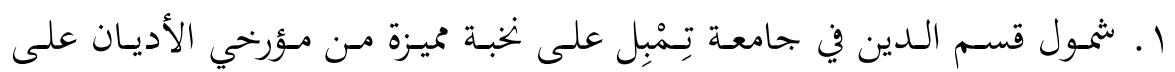

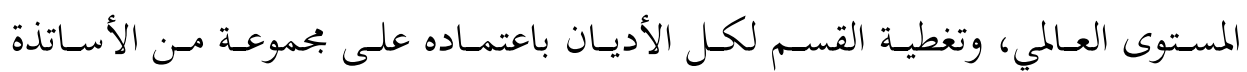
الدوليين المشهورين، وعدد من الطلاب الدوليين الممثلين لكل أديان العالم.

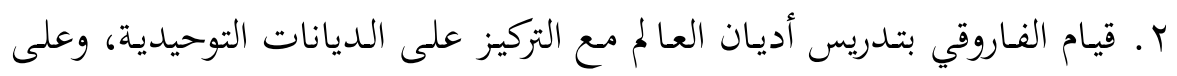
البعد المقارن بين اليهودية، والمسيحية، والإسلام. r. المساهمة في جهود قسم الدين بجامعة تِمْبِل في إرساء قواعد الحوار بين الأديان،

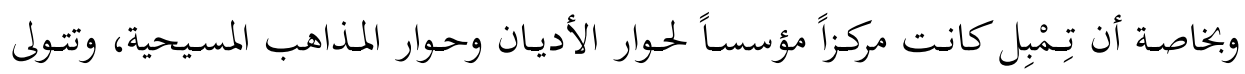

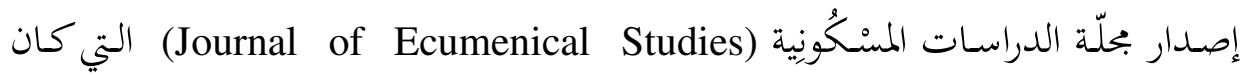

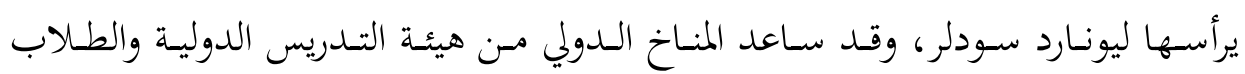

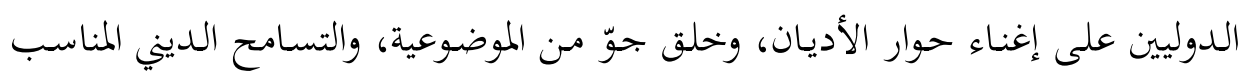
لنشأة الحوار وتطوره. 
ـ ـ مشاركته المنهجية مع كبار مؤرخي الأديان في وضع الأسس المنهجية لعلم تاريخ

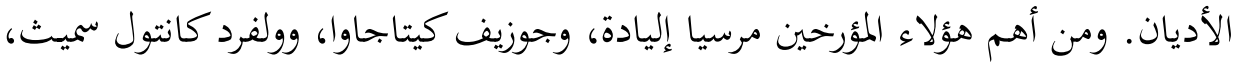

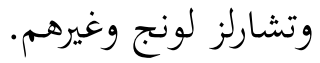
هـ المساهمة في التأسيس لحوار الأديان، وبخاصة الحوار الإسلامي المسيحي، والحوار

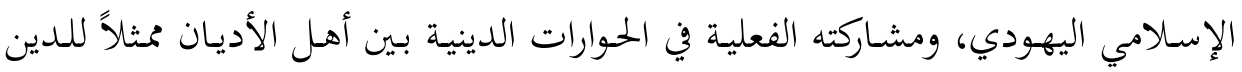

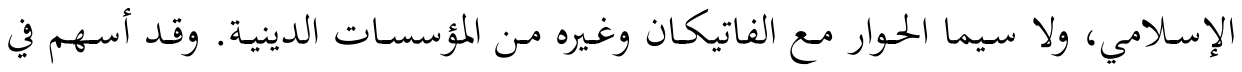

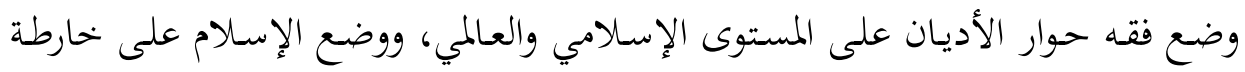

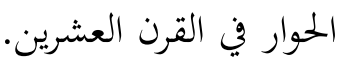

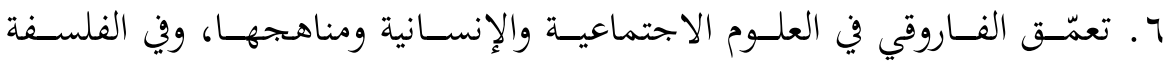

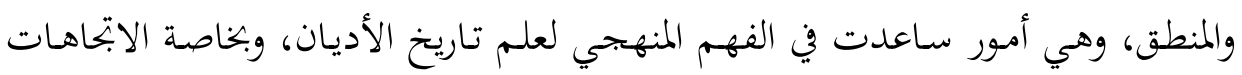

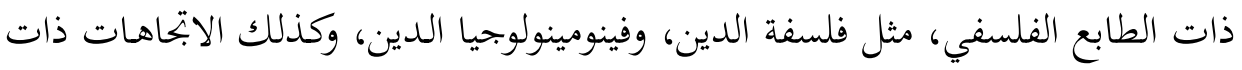

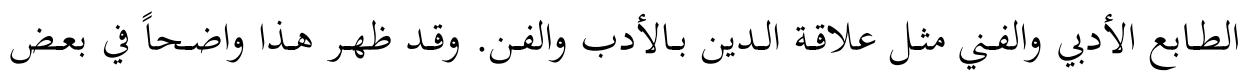

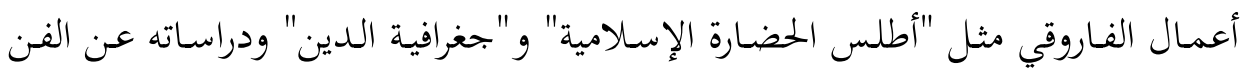

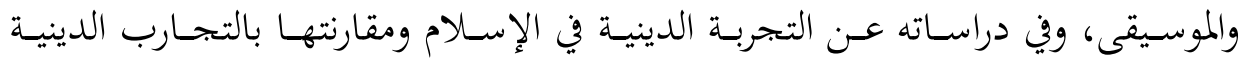

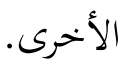

ويتطلب الأمر الكشف عن جهود الفاروقي في بحال دراسة الدين والأديان، وموقفه

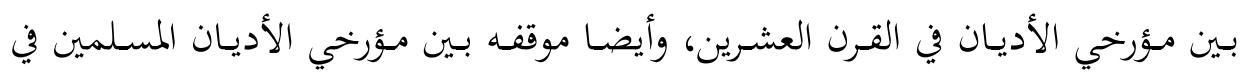

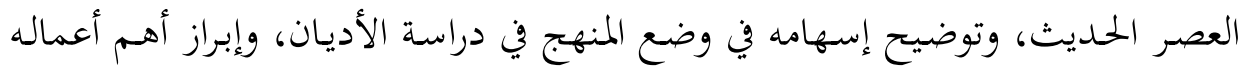

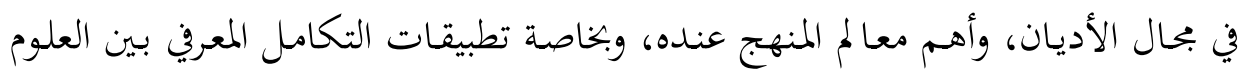

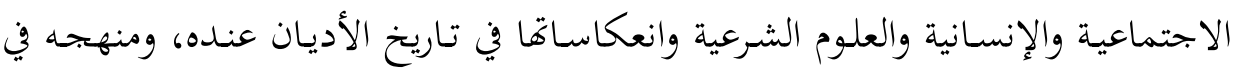
تقديم الإسلام ومقارنته بالأديان الأخرى.

\section{أولاً: جوهر التجربة الدينية مع التطبيق على الإسلام}

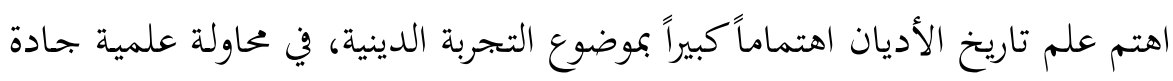

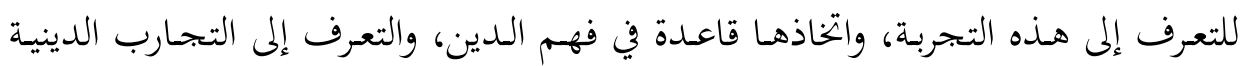


المختلفــة التي قـدمتها الأديـان المختلفـة، وتحديـــ المشـترك في هـــه التجربـة بـين الأديـان،

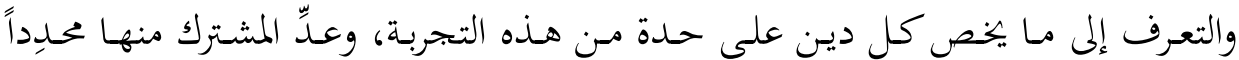

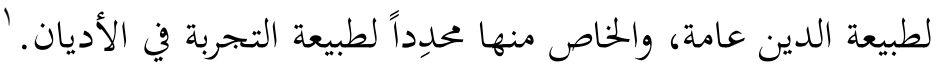

وقـد انشـل الفـاروقي بموضـوع التجربـة الدينيـة على مستـوى المـنهج في علمم تـاريخ

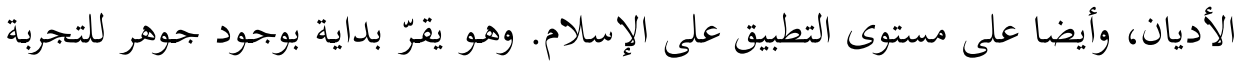

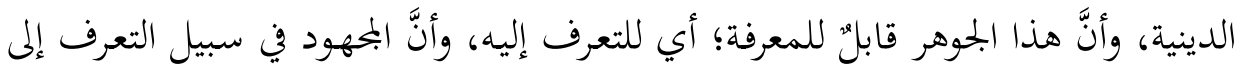

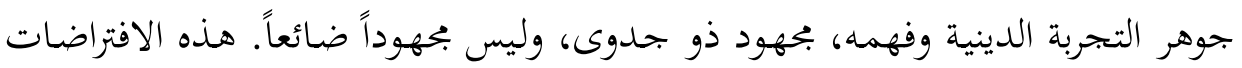

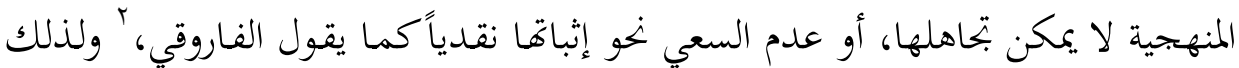

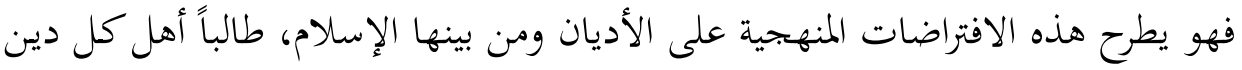

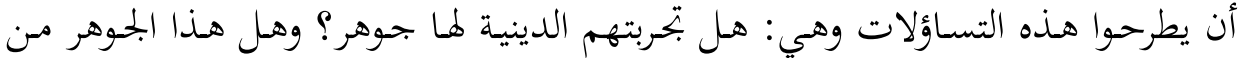

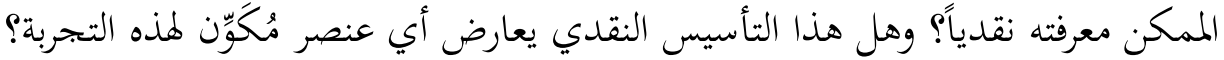
وين الإجابـة الإسـالامية عـن هـذه التسـاؤلات، يجيـب الفـاروقي أنه على الرغم مـن

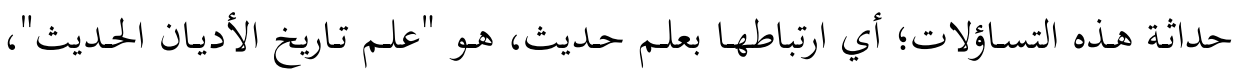
فهي مقبولة، والرد عليها إيجابي من وجهة النظر الإسلامية. فالإسلام له جوهر، وهو دين

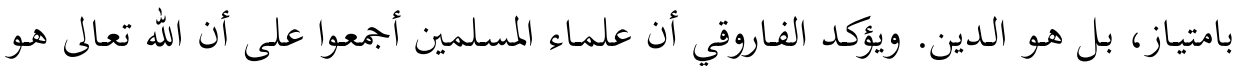

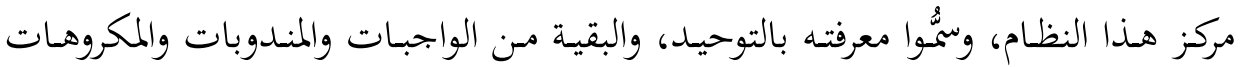

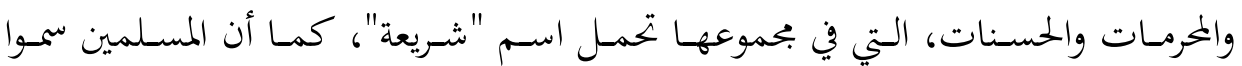

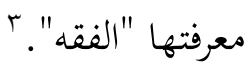

ومن أهم الدراسات والبحوث التي تناولت موضوع التجربة الدينية و تطبيقاته في الأديان مايلي: - James, William. The Varieties of Religious Experience, London: Longmans,1929.

- Leeuw, G. Van Der. Religion in Essence and Manifestation, London: Allen and Unwin, 1938.

- Wach, J. Types of Religious Experience, Chicago: Univ. of Chicago Press, 1951.

${ }^{2}$ Al Faruqi, Ismail Raji. "The Essence of Religious Experience in Islam" in his, Islam and other Faiths, edited by Ataulah Siddiqui, UK: The Islamic Foundation , and the USA: International Institute of Islamic Thought, 1998/1419H, p 3.

${ }^{3}$ al Faruqi, Ismail R. and al Faruqi, Lois Lamya. The Cultural Atlas of Islam, London and New York: Macmillan Pub Co, \& Collier Macmillan Publishers, 1986. 


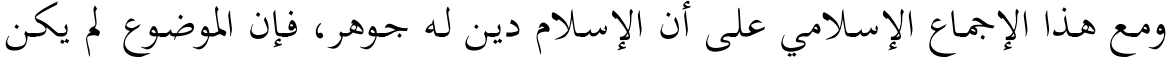

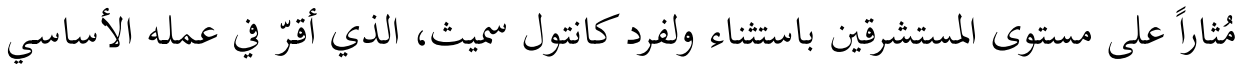

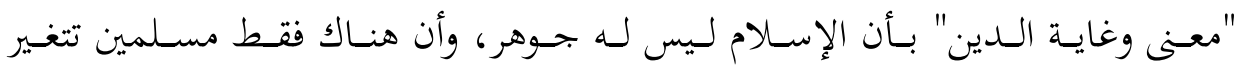
إسلاميتهم Musliminess كل صباح.

وتُعدّ هذه نقطة فارقة بين رؤية المسلمين لدينهم ورؤية المستشرقين للإسلام، وهي

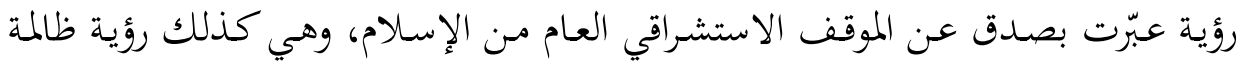

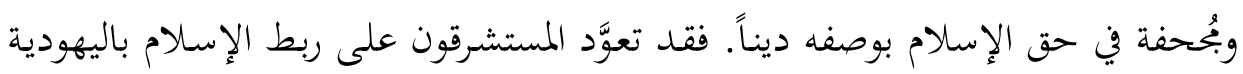

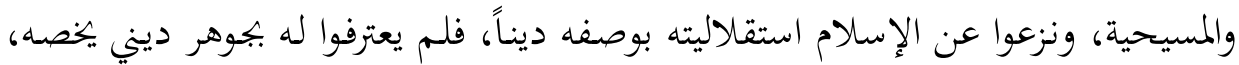
أو تجربة دينية تخصه، فهو ليس إلا انخرافاً أو خروجاً عن التجربة اليهودية المسيحية.

\section{ثنانياً: تأثر الفاروقي بالمنهج في علم تاريخ الأديان الحديث}

أفـاد الفـاروقي -بـلا شـك- مـن التطور المنهجي لعلـم تـاريخ الأديـان في العصر

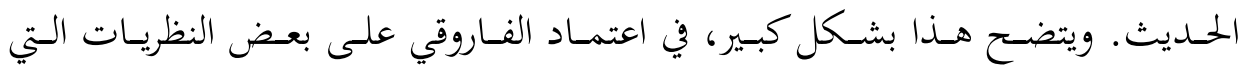

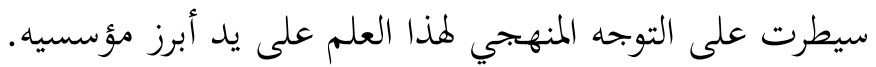

وقد جمع الفـاروقي بين منهجي فان درليو ويواكيم فاخ في كتاب (أطلس الحضارة الإسلامية). ويُعدّ أطلس الحضارة الإسلامية The Cultural Atlas of Islam من أبرز

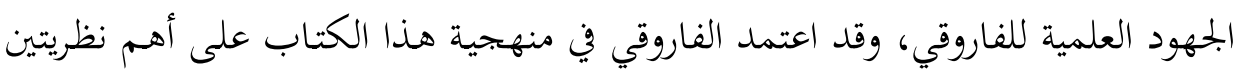

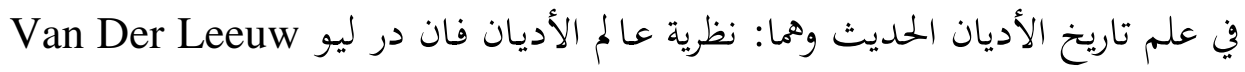

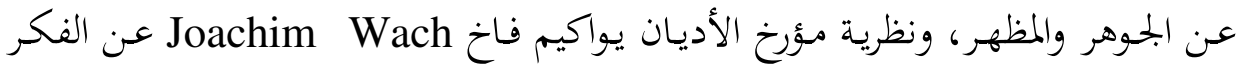

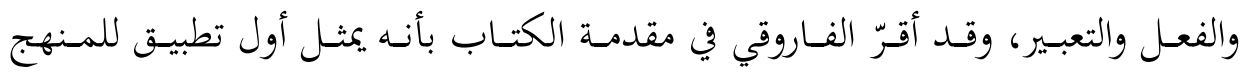
الفينومينولوجي على الإسلام وحضارته بوصفه كلاً.

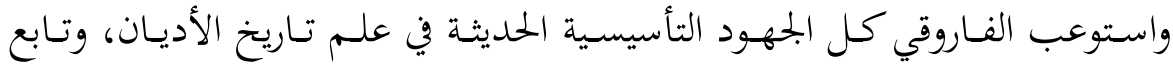

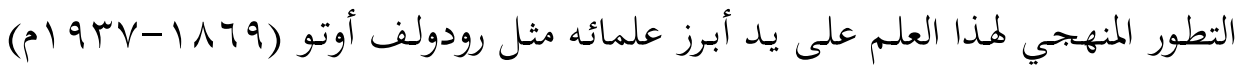

${ }^{4}$ Ibid, P 17. 
،W. Brede Kristensen (م) وبريد كرستنسن Rudolf Otto

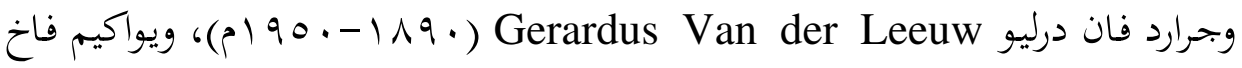

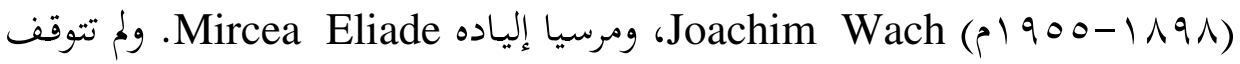

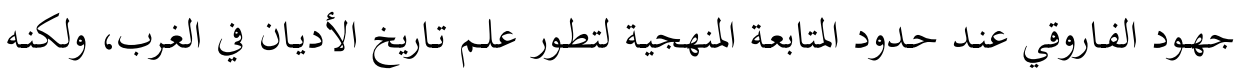

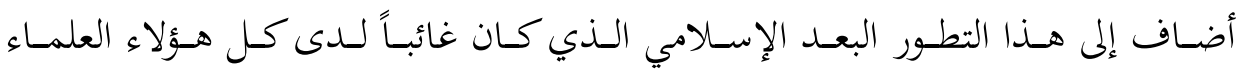

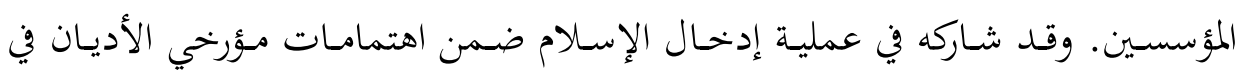

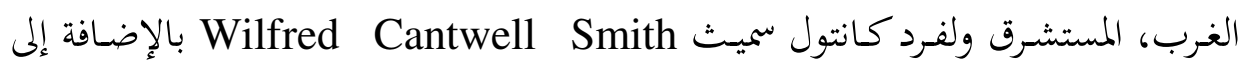

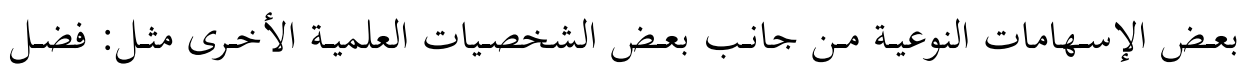

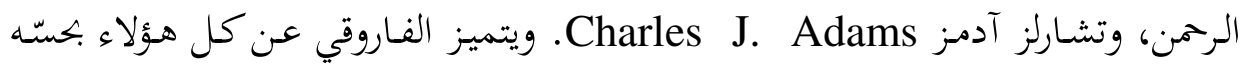

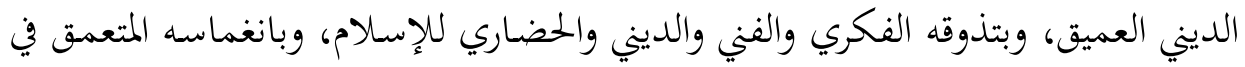

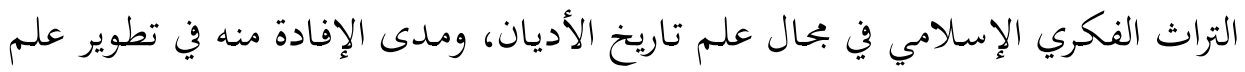

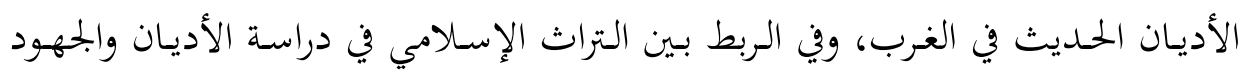

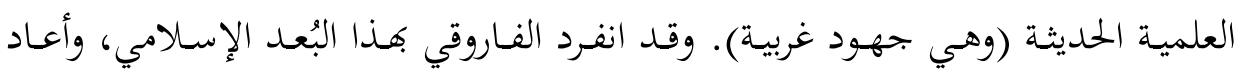

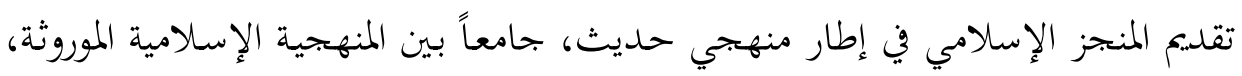

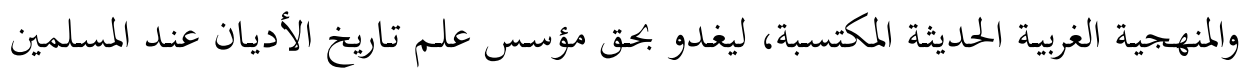

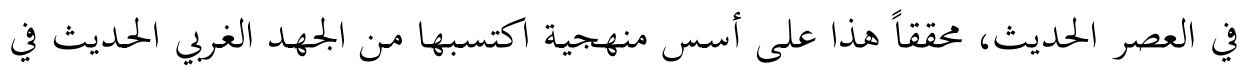
تطوير هذا العلم.

ويصف تشـارلز آدمز حالة الإسلام في علاقته بـالتطور المنهجي الحـديث في علم

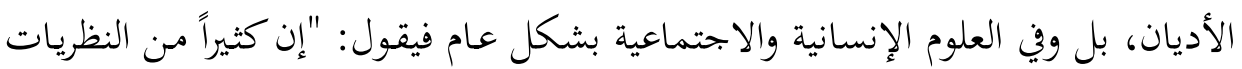

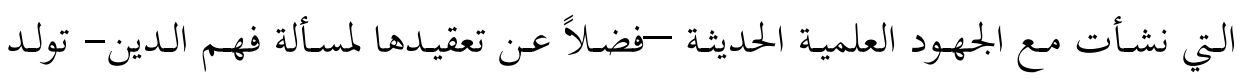

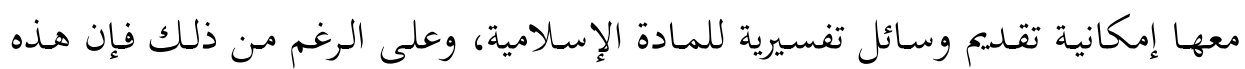

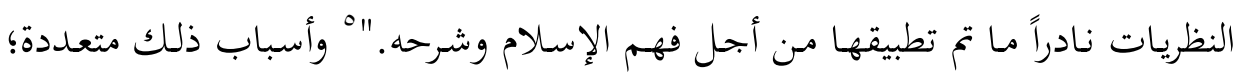

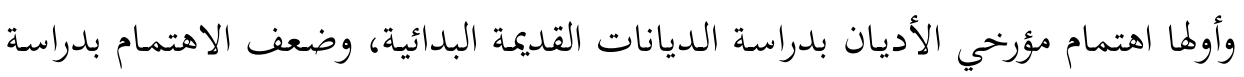

5 Adams, Charles J. "Islamic Religious Tradition" in, The study of the Middle East, edited by Leonard Binder, New York and London: John Wiley Sons, P. 32. 
الأديـان المتقدمـة. والسبب الثاني هـو الإهـال النسبي لدراسـة الإسـلام في العلـم الغربي

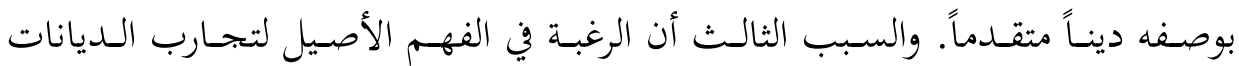

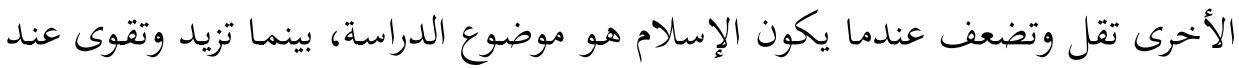

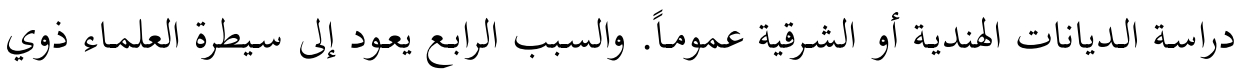

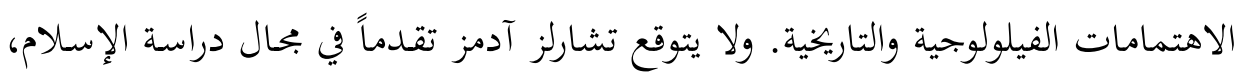
إذا لم يتم تطبيق نظريات تاريخ الأديان ومناهجه التي طُبقت على دراسة الأديان عموماً. ويعد (فان در ليو) مـن أهـم مؤرخي الأديان وعلمـاء ظاهريات الدين الذين تأثر

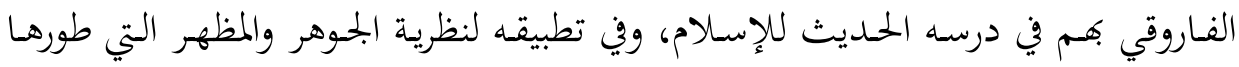

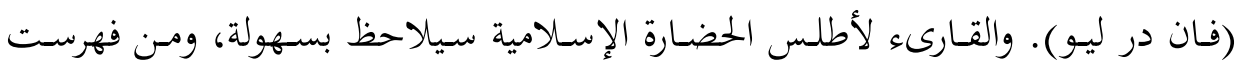

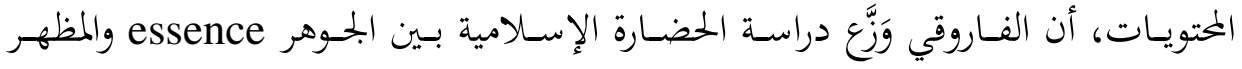
manifestation

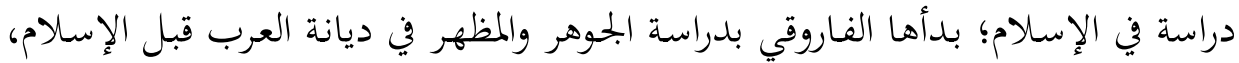

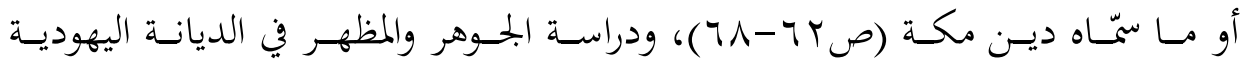

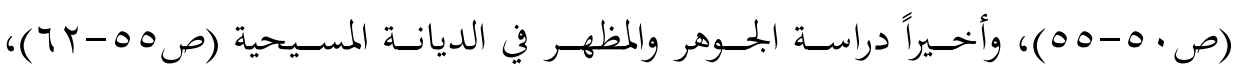

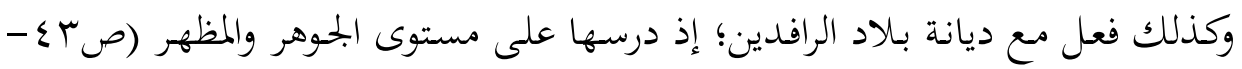

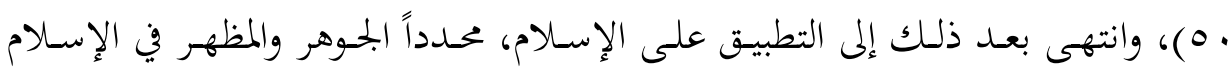
وحضارته.

وقد اتخذ الفاروقي من كتاب (فان در ليو): "الدين في الجوهر والمظهر" Religion in Essence and Manifestation

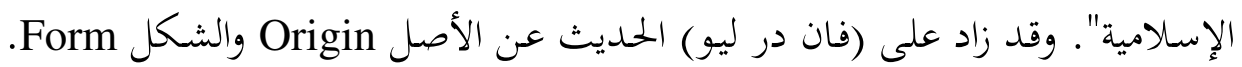

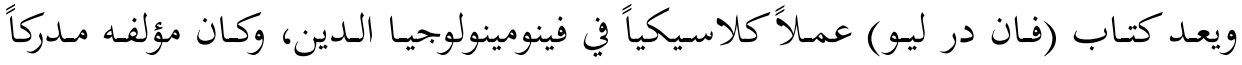
للبعد الشخصي العميق للدين، ولديه حساسية قوية بتحاه البعدين الفني والثقافي للظاهرة 
والحقيقة أننا بجد تشاهاً ملحوظاً بين شخصيتي (فان در ليو) والفاروقي، ولا نعتقد أن يكون هناك تأثر على المستوى الشخصي؛ إذ إفما لم يلتقيا بسبب البعد الزمني، فقد إند

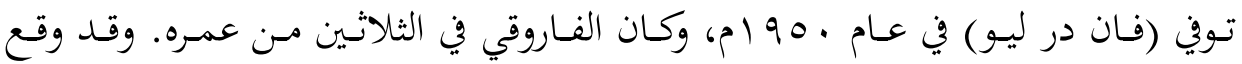

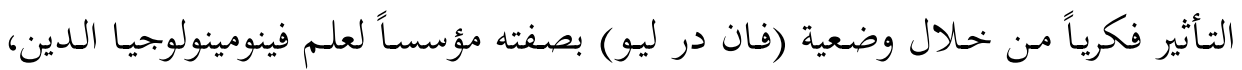

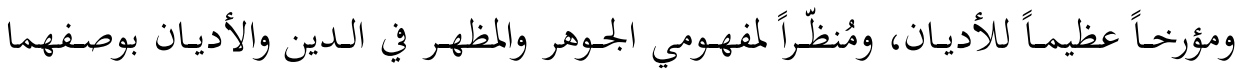

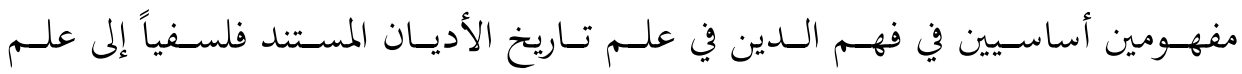
الفينومينولوجيا، الذي أنتج في النهاية فينومينولوجيا الدين. ولعل من أهم وجوه التأثير والتشابه بين (فان در ليو) والفاروقي، هذا الوعي العميق للأبعاد الشخصية والفنية والثقافية للتجربة الدينية، ونحن نتلمسه جلياً في كتابي: "الدين في الجوهر والمظهر" و "أطلس الحضارة الإسلامية"، كما نتلمسه في القاعدة الفلسفية التي انطلق منها (فان در ليو) والفاروقي، وهي القاعدة الفينومينولوجية؛ إذ اعترف (فان در ليو) بوضعية مستقلة لفينومينولوجيا الدين بوصفه علماً مستقلاً، مع النظر إليه على أنه Loving علـم منشـغل -بالضـرورة- بالاهتمامـات اللاهوتيـة وبالمعرفـة الـمُحبِّة Knowledge، فعا لم الظاهرة الدينية يتمتع بلحظتين: اللحظة الإيمانية واللحظة المعرفية،

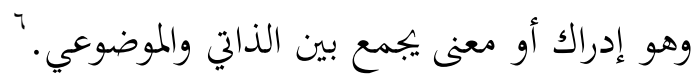

وقد بتحاوز (فان در ليو) حدود الفهرسة المنظمة الدقيقة، وتصنيف الظواهر الدينية إلى حالـة يسـتطيع معهـا دارس الـدين أن يعيـــ بحربـة الحيـاة الداخليـة للظـواهر الدينيـة

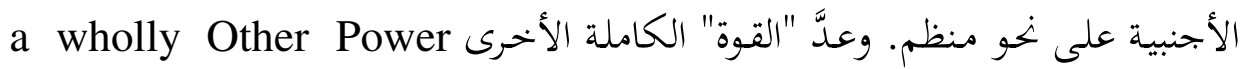
موضوعاً للتجربة الدينية. وهي "قوة" قريبة من فكرة القداسة Holiness عند ناثان سودر

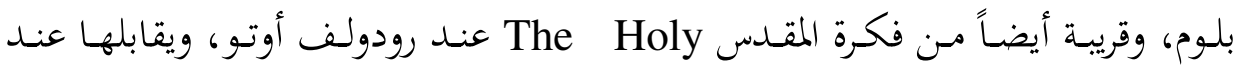
الفاروقي مفهوم التوحيد الذي يعده جوهر الإسلام. وهذه القوة عند (فان در ليو) تأخذا

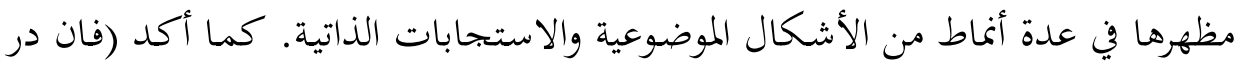

${ }^{6}$ Cain, Seymour. "Study of Religion: Methodological Issues" in Mircea Eliade (ed.), The Encyclopedia of Religion, Vol. 14, Macmillan Pub. Co, New York and London, 1987, P75. 


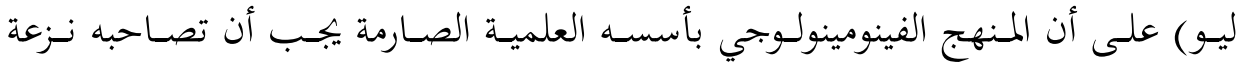
لا هوتية معينة.

وقد كان (فان در ليو) مسيحياً مؤمناً وبروتستانتي المذذهب، واعتمد على مـنهج

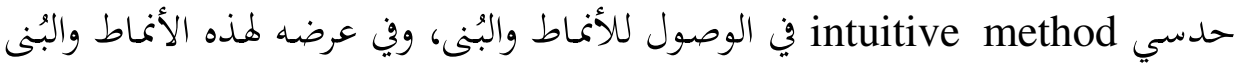

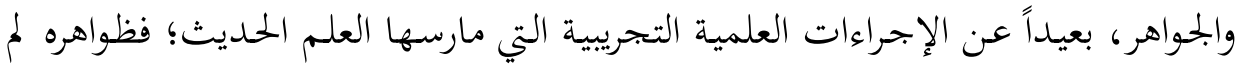

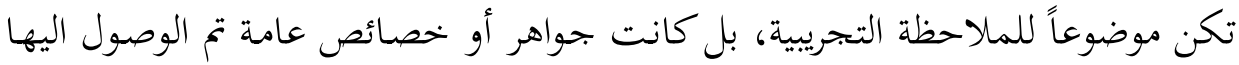

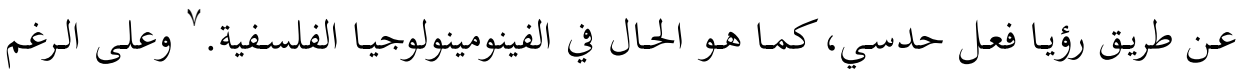

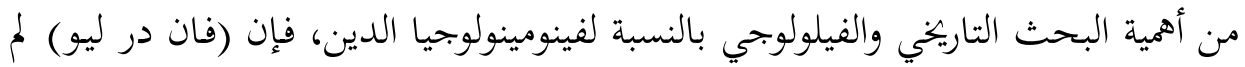

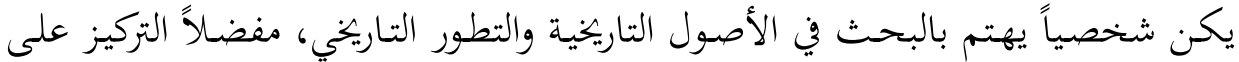
تقديم الأنماط والبُنى والجواهر.

وإذا عدنا إلى الفاروقي سنجد عدة أمور منهجية متقاربة أو متشاهمة مع منهج (فان النهان

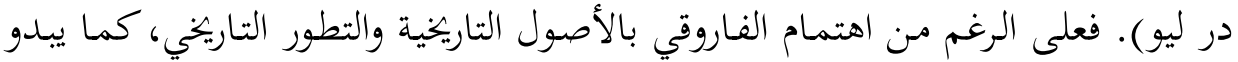

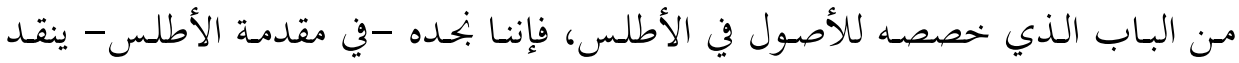

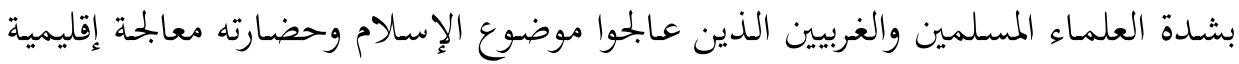

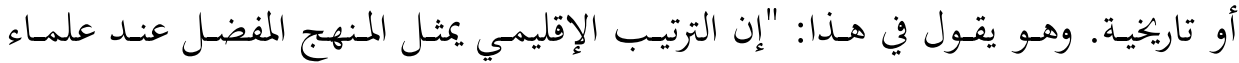

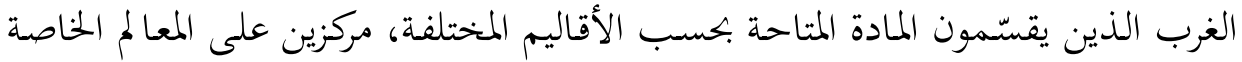
بتاريخ منطقة ما."

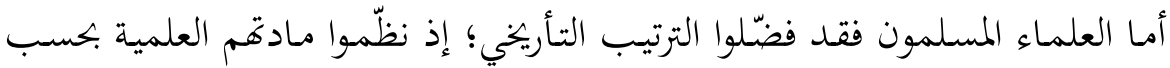

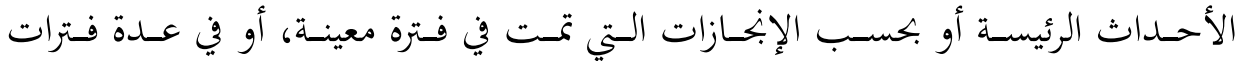

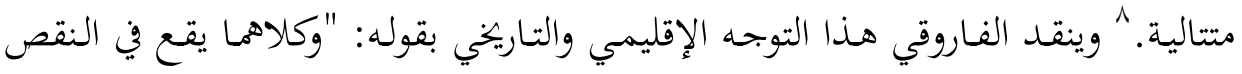

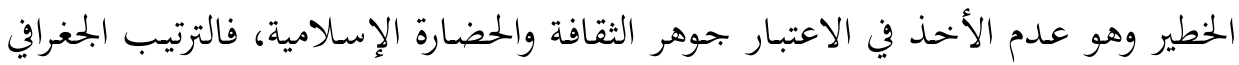

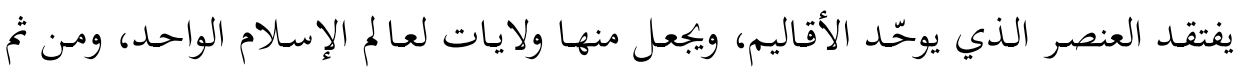

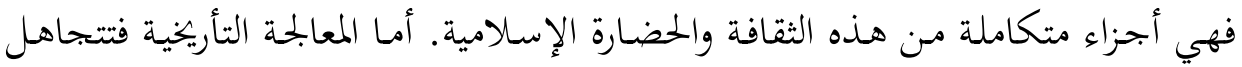
${ }^{7}$ Ibid,P75.

${ }^{8}$ The cultural Atlas of Islam,P.12. 
المادة التي استمرت خهلال أحداث القرون والأجيال، التي نسجت هـذا التنوع المذهل للتعبير في وحدة عضوية ثقافية وحضارية.

ولم تنجح الكتب التي جمعت بين الترتيب الإقليمي والتأريخي؛ لأغها جمعت نواقص

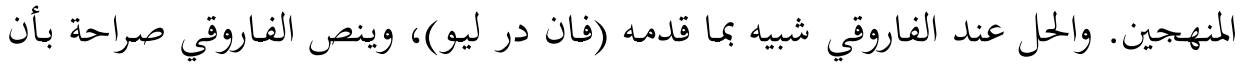

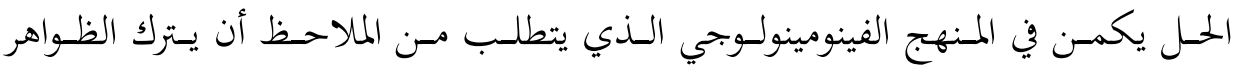

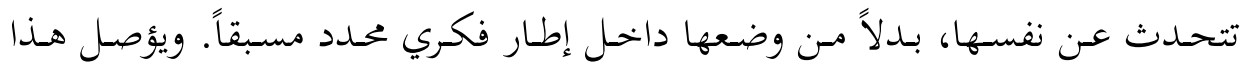

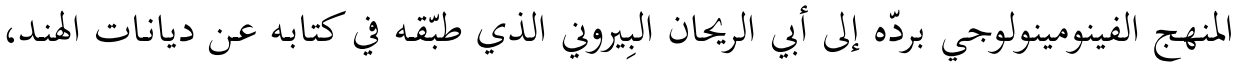

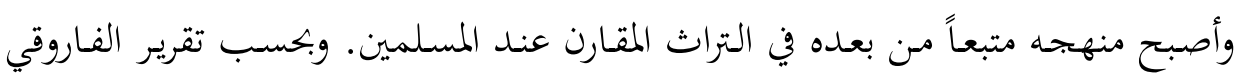

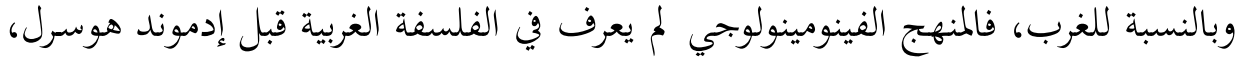

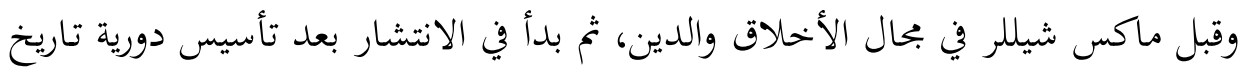

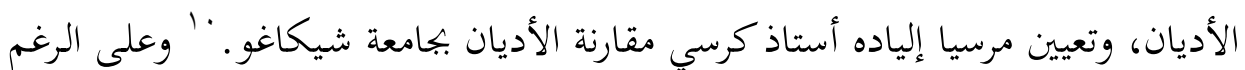

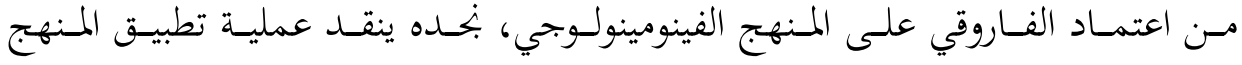

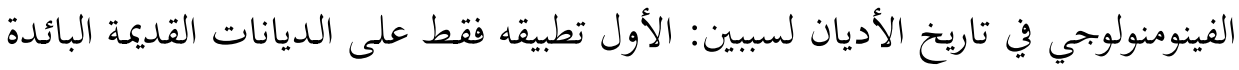

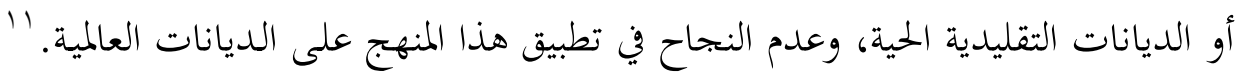

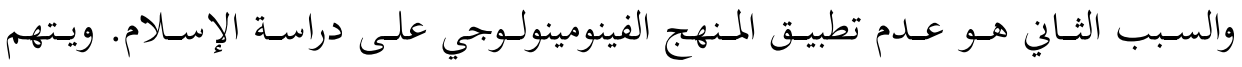

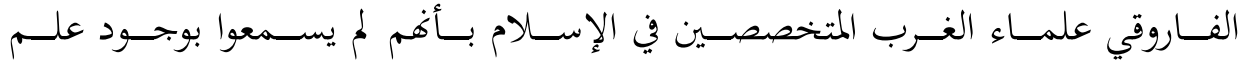

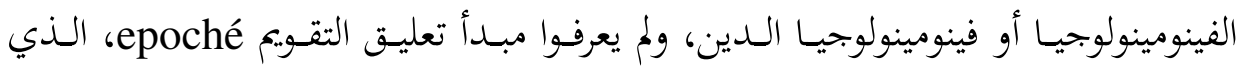

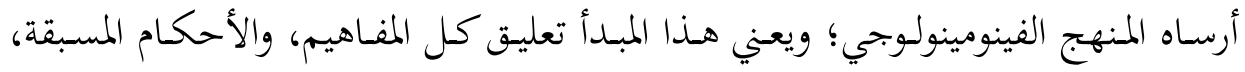

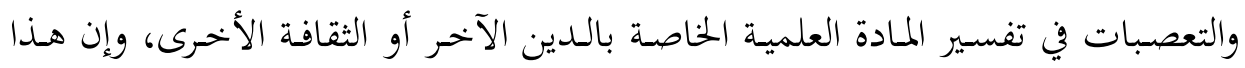

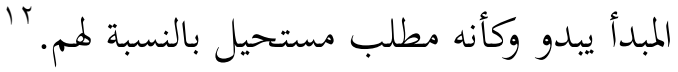

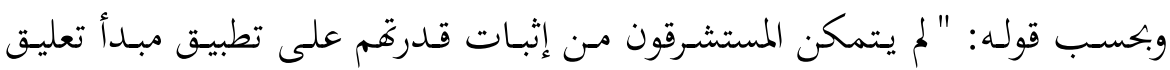

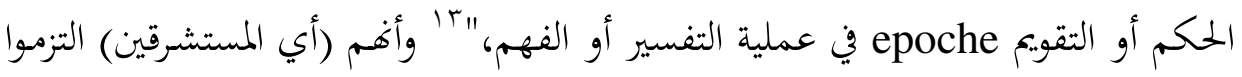

\section{${ }^{9}$ Ibid, P12.}

${ }^{10}$ The Cultural Atlas of Islam,P.12.

${ }^{11}$ Ibid., P. 13.

12 Ibid.

13 Ibid. 
بإيديولوجيات معرفية مركزية عرقية أو إدراك الحقيقة وفقاً للعِرق والإثنية، وأن هذا الالتزام المعرين الإثني اضطرهم إلى أن يصبحوا إقليميين في فهمهم للتاريخ. كما أن المنهج العلمي الذي يعـد "الحقيقي" فقط مـا هـو حسي، ومـادي، وكمي، ومـا يمكن قياسهـ..... هـذا المـنهج ربـط المستشـقين بـالمظهر الخـارجي وأعمـاهم عـن الجـوهر الـذي تمثلـه الظـاهرة.

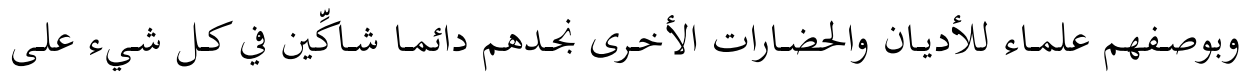
المستوى القيمي والعـالمي، وينظرون إلى مثل هـذه المعلومـات أوالحقـائق data على أهـا نسبية وذاتية أو حتى شخصية. ويرد الفاروقي غياب الموضوعية في التعامل مع المادة الإسلامية أيضاً إلى تراث العِداء والمواجهة بين الغرب والإسلام، الذي توارثه هؤلاء المستشرقون جيلاً بعد جيل. ه' لهذه الأسباب بحتمعـة يعـد الفـاروقي كتابـه (أطلس الحضـارة الإسـلامية) أول تطبيـق للمـنهج الفينومينولوجي على الإسلام وحضارته. وقد جمع الفاروقي بامتياز بين منهج (فان درليو) الخاص بالجوهر والمظهر، ومنهج (يواكيم فاخ) الخاص بـالفكر والفعل والتعبير، ويشرح الفـاروقي في مقدمـة الأطلس هـا المنزج بـين منهجي (فـان در ليو) و(فاخ) على النحو الآتي: "من الممكن الادعاء بأن هذا الكتاب هو أول تطبيق للمنهج الفينومينولوجي على الإسلام وحضـارته ككل؛ فالكتاب يبدأ بدراسة للمهد الذي يمثل الواقع التاريخي الذي

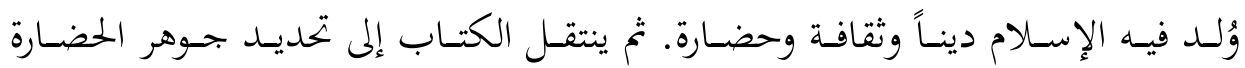

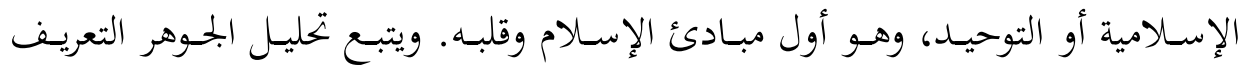
بالشـكل معطى في نظـام للأفكـار، وهــــ نظـام للتحقيـق المثـالي ونظــام للمؤسسـات الاجتماعية. وقد صاغت هذه العناصر الثلاثة مشتركةً الثقافة والحضارة الإسلامية، معطية لهـا صفتها وشـكلها، ومميزة لعمقها وأبعادهـا، ومحـددة لمسـيرتا ولتطورهـا في التـاريخ". ويوضـح هـذا التحليـل اعتمـاد الفـاروقي على مفهـوم الجـوهر والمظهـر في تحديــ طبيعـة الإسالام وخصائصه.

14 Ibid.

15 Ibid. 
أما بالنسبة لمنهج (فاخ) والإفادة منه في عرض الإسالام وحضارته، فنتوصل إليه من خهال قـول الفـاروقي: "وفي النهايـة نعـرض مظـاهر الإسـام في ظـواهر الثقافـة والحضـارة تحت مقولات الفعل، والفكر، والتعبير معطين تقريراً منظماً عن حقول النشاط الإنساني المناسبة". وقد نص الفـاروقي على أن الفصلين التاسع والعاشر يعالجحان المظهر في الفعل

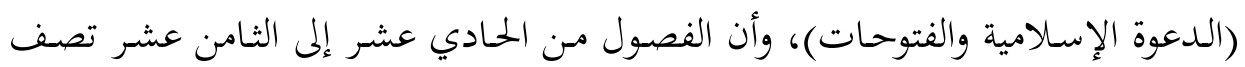

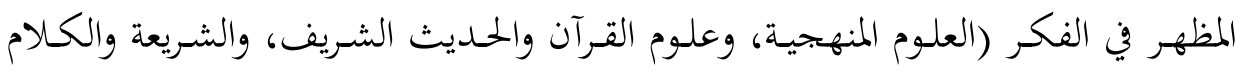
والتصوف، والفلسفة، والنظام الطبيعي) وأن الفصول مـن العشرين إلى الثالث والعشرين

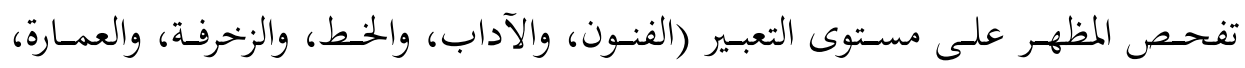
وهندسة الصوت، أو فن الصوت).

وتظهر عملية الجمع بين منهجي (فان در ليو) و(فاخ) عند الفاروقي في أن عنصر

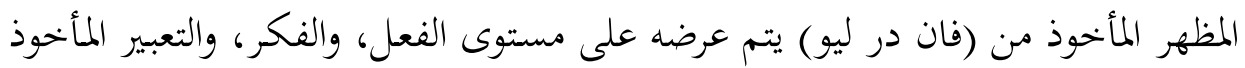
من (فاخ). ولعل الفاروقي في مشروعه الخاص بأطلس الحضارة الإسلامية أراد أن يقوم بما

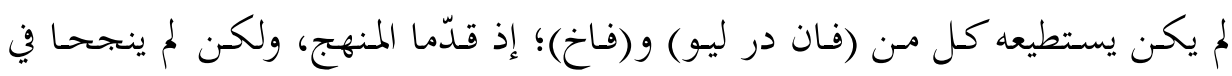

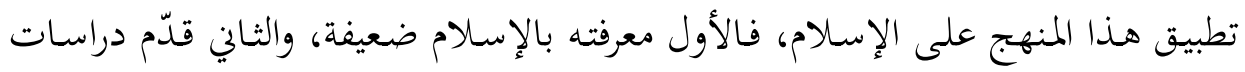
هامشية على مستوى الإسلام. 17

ويجب أن نعترف بهذه الحقيقة وهي أن الفـاروقي كان الوحيد من بين علماء تاريخ الأديان في الغرب الذي تمكن من تطبيق منهج فينومينولوجيا الدين على الإسلام. ويمكن بـان

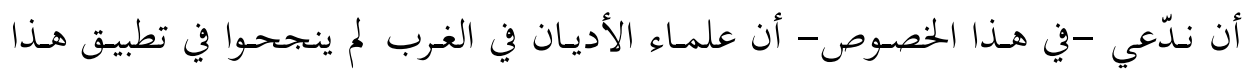
المنهج على أي من الديانات العالمية، فدراستهم ركّزت على الديانات البدائية والتقليدية،

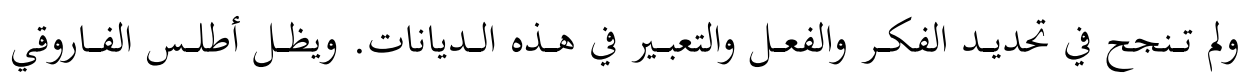
علامة مميزة وفارقة في الدرس المنهجي في تناول الظواهر الدينية.

- Types of Religious Experience, Chicago 1951

$$
17
$$

أما نظرية الفكر والفعل والتعبير فقد قدمها فاخ في كتابه: - The Comparative Study of Religions edited by Joseph Kitagawa, Colombia Univ. Press1958. 
ولأسـف الشــيد أن علمـاء المسـلمين في العصـر الحسديث لم يفيـدوا مـن عمـل

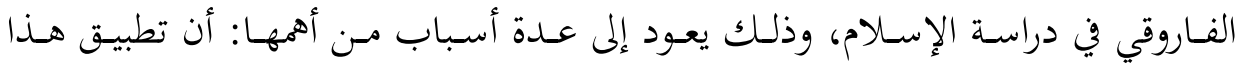

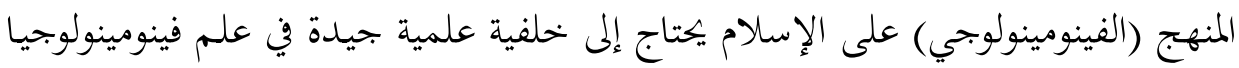

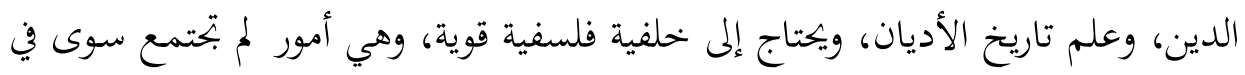

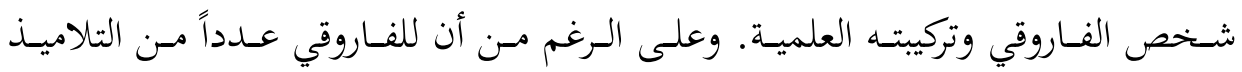

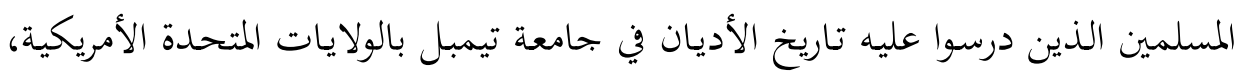

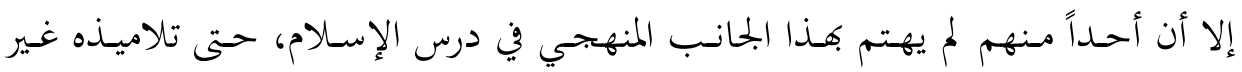

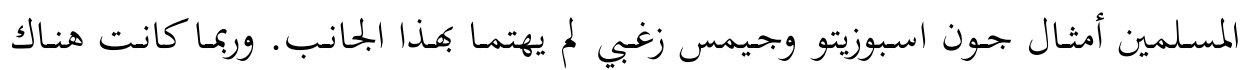

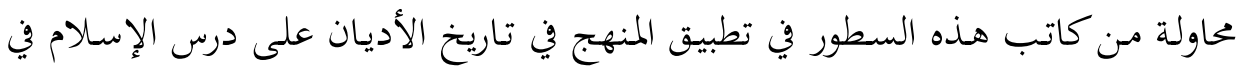

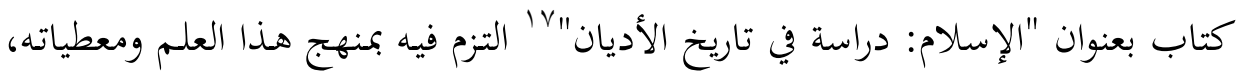

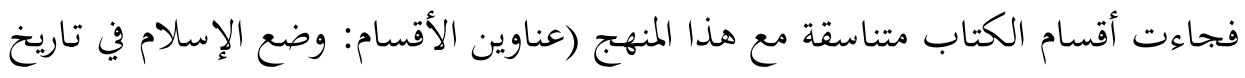
الأديان -وجوهر الإسلام- وطبيعة التجربة الدينية في الإسلام- والبنية الدينية للإسلام).

\section{ثالثاً: وجوه التشابه بين الفاروقي، وفان در ليو، وفاخ وسميث}

لم يكن المنهج في دراسة الأديان والإسلام هو فقط الجامع بين الفاروقي وعلماء

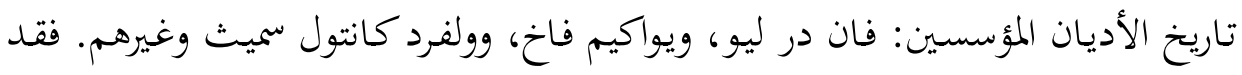

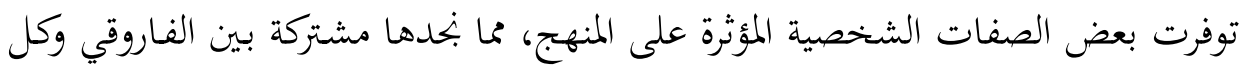
من فان در ليو، وفاخ، وسميث، ونوجزها فيما يأتي:

\section{1 ا ـ البعد الشخصي العميق تجاه الدين والتجربة الدينية:}

ويمكننا في هذا الشأن أن نقسّم مؤرخي الأديان إلى بحموعتين صريحتين: البمموعة

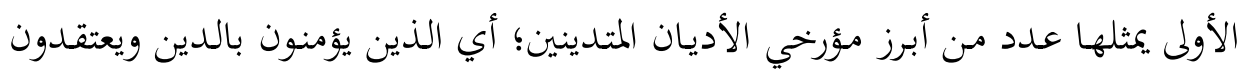

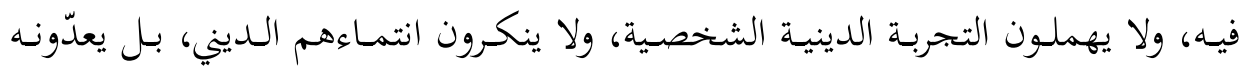

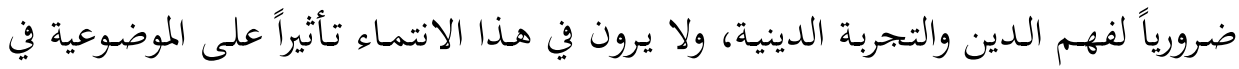


دراسة الدين والأديان الأخرى. ويمثل هذه البمموعة بقوة كل من فان درليو، ويواكيم فاخ، وولفرد كانتول سميث، وهي المجموعة المؤثرة على الفاروقي منهجياً، على الرغم من انتماء

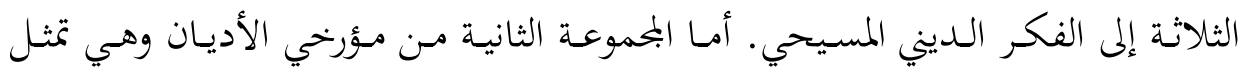

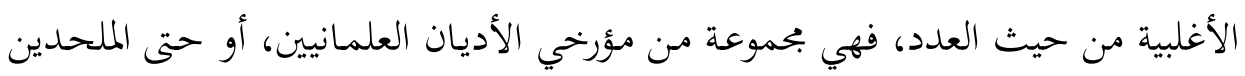

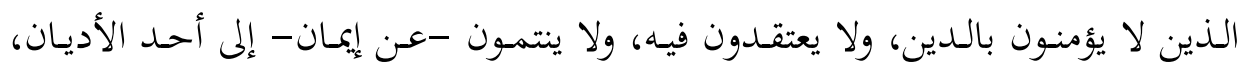

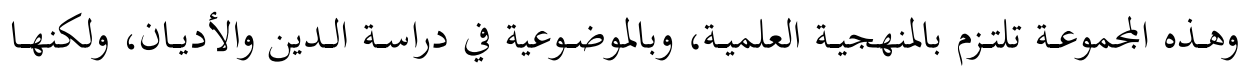
تفتقد بالطبع الروح الدينية الناجمة عن الانتماء الديني، والاعتراف بالدين والأديان، بل والمنبثقة عن بتربة دينية خحاصة مرتبطة بالدين الذي ينتمون إليه، والتجربة الدينية العامة

هذا الالتزام الديني الشخصي ضمّ الفاروقي إلى بحموعة فان در ليو، وفاخ وسميث،

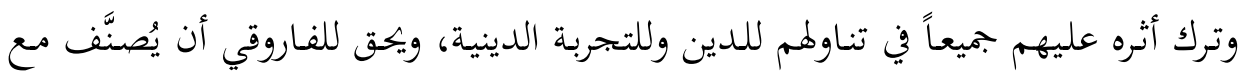

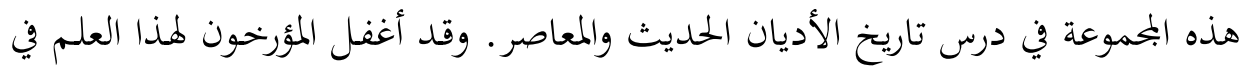

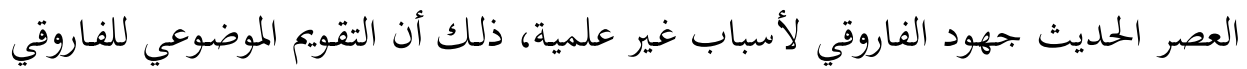

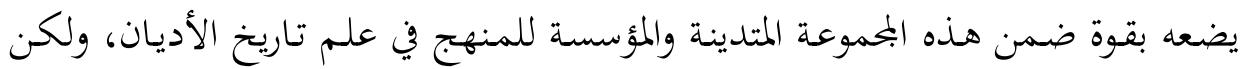

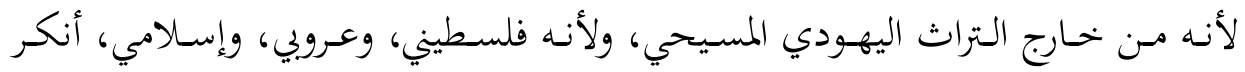

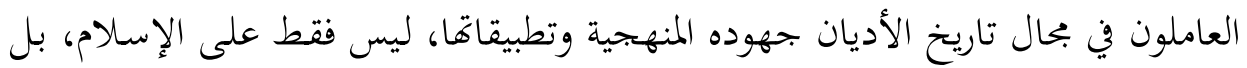

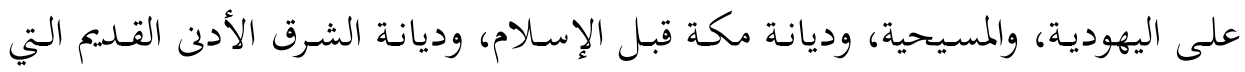

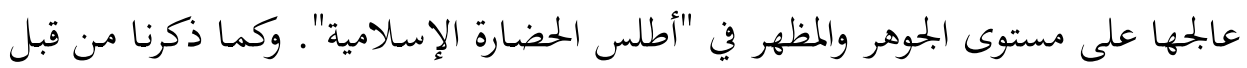

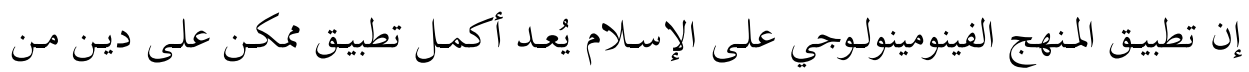

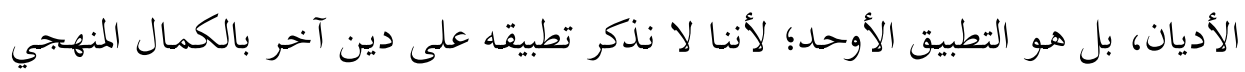

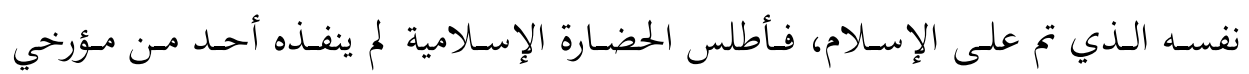

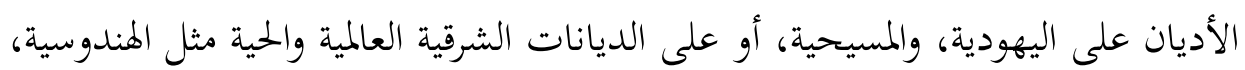
والبوذية وغيرها.

ويعـد "الأطلس "نموذجـاً منهجيـاً يمكـن الإفـادة منـه وتطبيقـه على أديـان العـالم

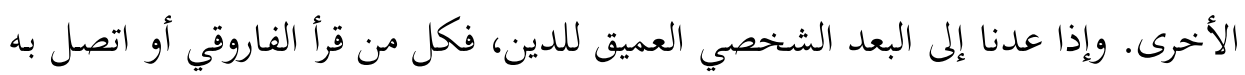


على المستوى الشخصي يدرك قوة تديّنه وأهمية الدين في حياته، ويدرك أيضاً ملامح من تجربته الدينية الشخصية داخل إطار التجربة الدينية الإسلامية العامة، وأيضاً داخل إطار

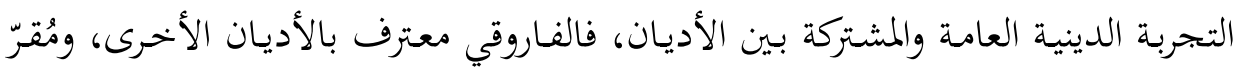

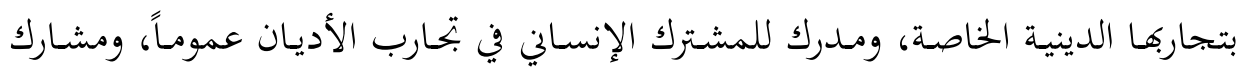
قوي وفعال في حوارات الأديان، بل ومؤسس لحوار الإسلام مع الأديان الأخرى.

\section{Y. النزعة اللاهوتية المصاحبة لمؤرخي الأديان موضوع المقارنة:}

وبالإضـافة إلى البعـد الشخصي العميق للـدين عند الفـاروقي، وفـان در ليو، وفـاخ وسميث، نلاحظ أيضاً وجود نزعة دينية أو ابتاه ديني لاهوتي قوي في فكر هذه المحموعة. وهو ابتحاه صريح اعترف بـه هؤلاء في كتاباتمم وفي توجهاهم العلمية. لقد ذكرنا سـابقاً

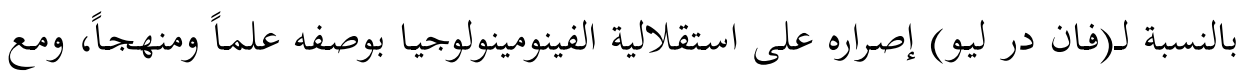
ذلك فقد أكد على ضرورة أن يصاحب ذلك موقف لاهوتي معين، وهذا الموقف في حالة

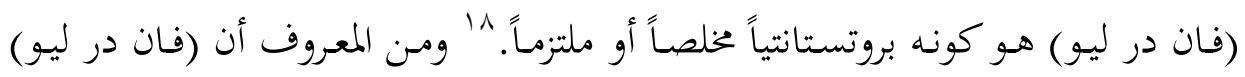

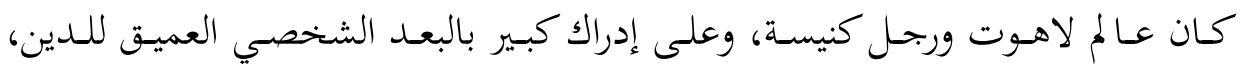

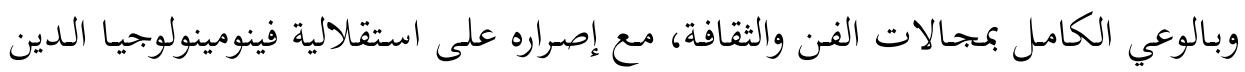
بوصفه علماً مستقالًا. فهو يرى ضـرورة انشغال هـذا العلم بالاهتمامـات اللاهوتيـة. 19

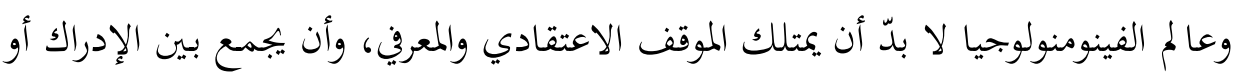
الوعي الذاتي والموضوعي.

أما (يواكيم فاخ) فهو يأتي أيضاً من خلفية بروتستانتية؛ إذ نشأ في أسرة تنتمي إلى الكنيسة اللوثرية بألمانيا، والتحق بعدها بالكنيسة الأسقفية البروتستانتية بالولايات المتحدة الأمريكية، مع استمرارية تأثير لوثر الروحي عليه. ويصف جوزيف كتياجاوا وضع (فاخ) الديني بأنه مسيحي إنساني مثالي، وأنه مسكوني التوجه، ورجل الكتاب المقدس ومؤمن،

${ }^{18}$ Cain. Seymour. "Study of Religion" in The Encyclopedia of Religion, ed. by Mircea Eliade, Vol.14,P 75.

${ }^{19}$ Ibid,P75.

${ }^{20}$ Ibid,P75. 


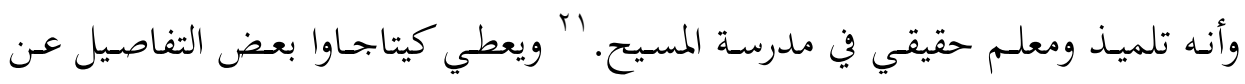

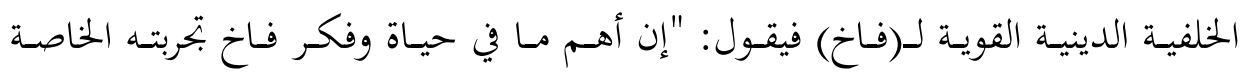
بالمسيح الحي living Christ متأثراً بتفسير بولس للمسيح مع ميوله إلى النمط اليوحني

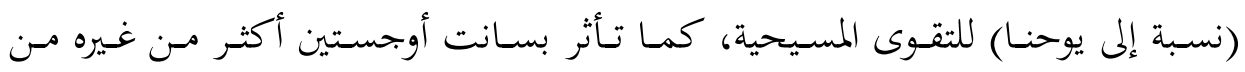

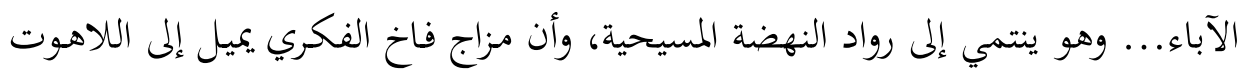

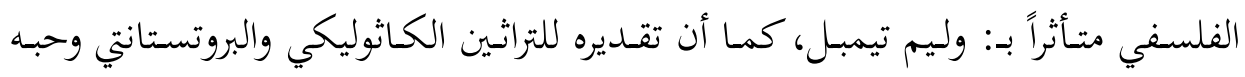

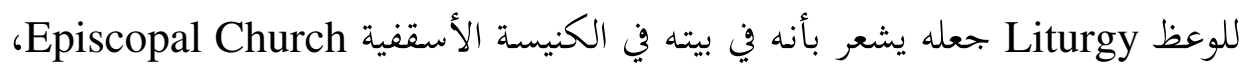

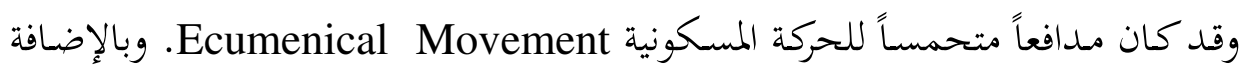

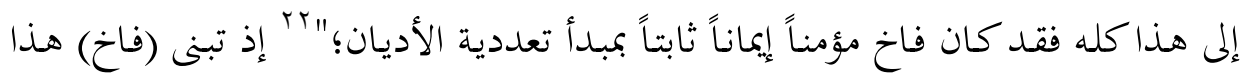

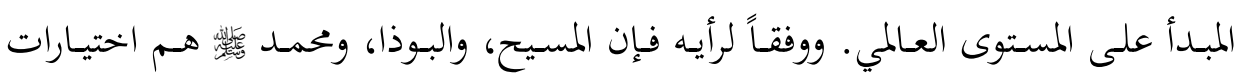

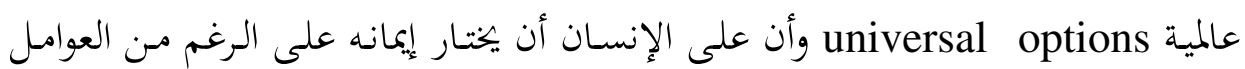
البيئية.

وقد حاول (فاخ) في كتابه "الدراسة المقارنة للأديان" الجمع بين رؤى ومناهج علم

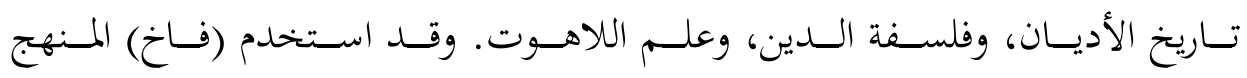

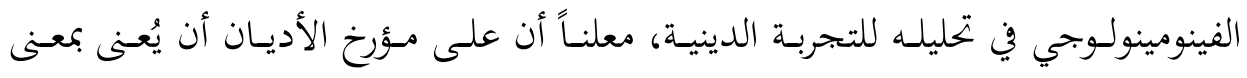

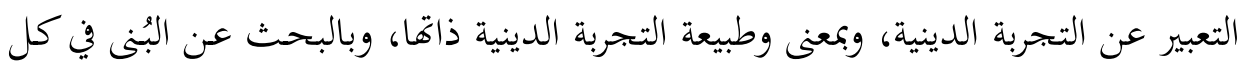

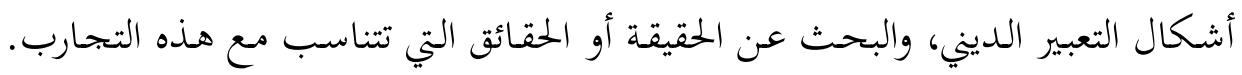

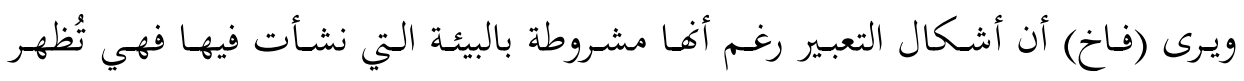

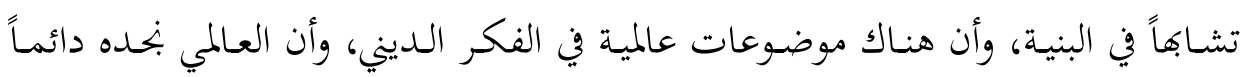

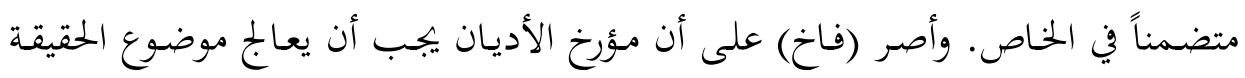

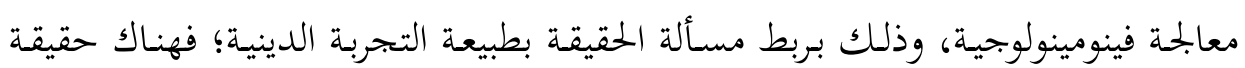

${ }^{21}$ Wach, Joachim. The comparative study of Religions, edited by Joseh M. Kitagawa , Columbia Univ. Press, 1958 P.36.

${ }^{22}$ Ibid., P. 36.

${ }^{23}$ Ibid., P. 22. 
واحسدة، ولكـن إدراك هـذه الحقيقـة الواحسدة يختلـف بحسـب اخستلاف وسـائل الإدراك

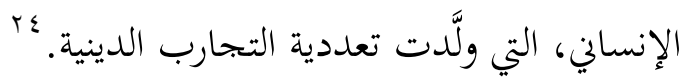

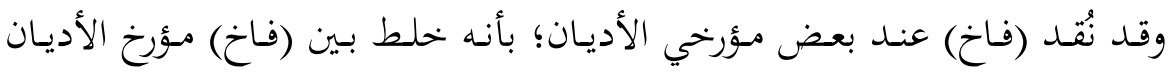

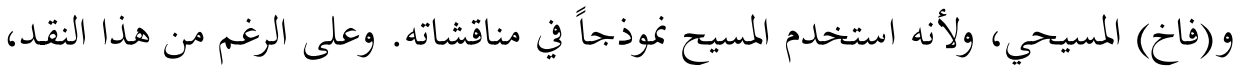
فقد جاهد (فاخ) من أجل الفصل بين الدراسة المقارنة للأديان، وعلم اللاهوت الدفاعي

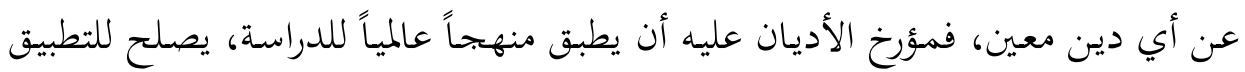

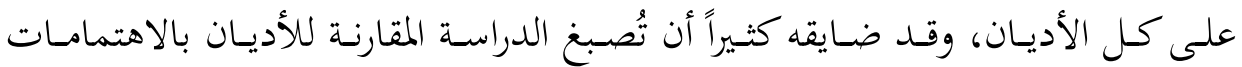

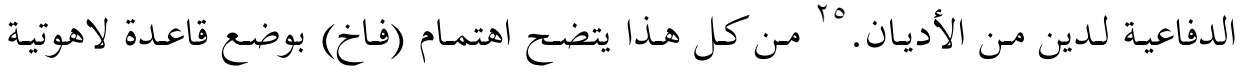

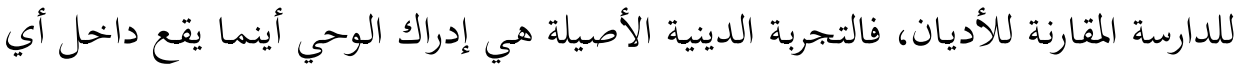
سياق إثني أو ثقافي أواجتماعي أو ديني. وقد وضع (فاخ) - بوصفه مؤرخاً للأديان - عدة مبادئ لعا لم اللاهوت المسيحي،

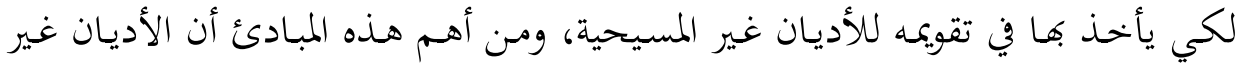

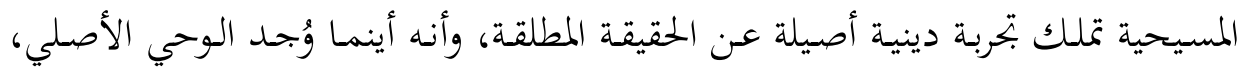

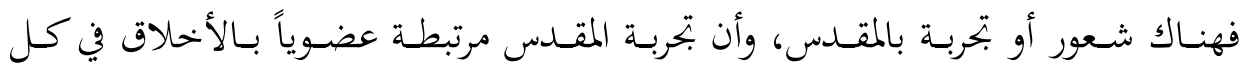
الأديان، وأن غير المسيحيين لديهم إدراك بالنعمة الإلهية، وأن هناك عدة أنواع ودرجات وركات لإدراك المقـدس في الـديانات غير المسيحية، وأن هنـاك شعوراً حقيقياً بالعبـادة في الـنظم

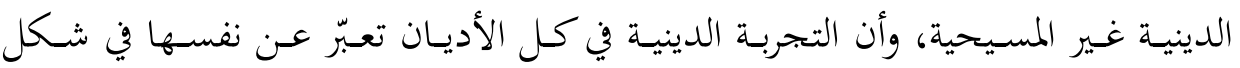
جماعي. وهكذا يعطى (فاخ) لتاريخ الأديان مكاناً ثابتاً في علم اللاهـوت، ليس فتط من

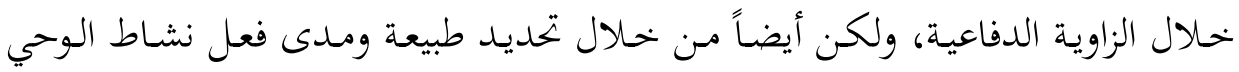

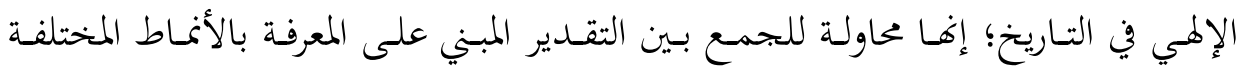

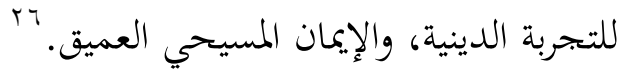

${ }^{24}$ Ibid., P. 41.

${ }^{25}$ Ibid., P. 42.

${ }^{26}$ Ibid., P. 14. 
وإذا عدنا إلى الفاروقي لوجدنا هذه التجربة نفسها التي مرّ بها كل من (فان در ليو)

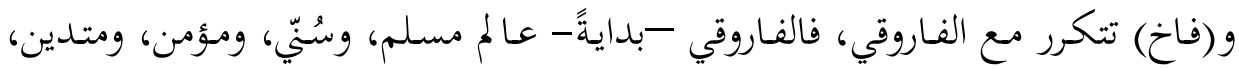

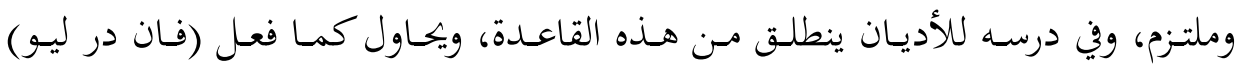
و (فاخ) أن يوفّق بين تدينه الصريح، والالتزام الموضوعي في درس الأديان الأخرى، وهو يفعل هذا باللجوء إلى المنهج الفينومينولوجي ذاته الذي سار عليه (فان در ليو) و(فاخ). لقد اهتم الفاروقي بالمنهج الفينومينولوجي، واتخذه أساساً منهجياً لعدد من دراساته، كما حدث مع (أطلس الحضارة الإسلامية). ولم يتوقف اهتمام الفاروقي بهذا المنهج عند حد التطبيق، بل اهتم بدراسة المنهج ذاته، والتعريف بإيجابياته وسلبياته من خهلال نقده نقداً علمياً. وقد وضّح الفاروقي في أكثر من موضع الاتحاهات المنهجية المهمة في دراسة الدين والأديان، وانتهى إلى تفضيل المنهج الفينومينولوجي الذي يتجنب العيوب المنهجية

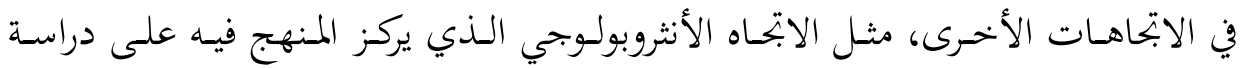
الديانات البدائية من خهال الملاحظة المباشرة للممارسات الدينية لأهل هذه الديانات، أو مـن خلال معلومات وأوصاف يتم الحصول عليها منهم. وقد انتقد هـا المنهج بأنه يعتمد على نظرية التطور، وعلى نظام معريف يعترف فقط بالمعلومات، أو المادة السلوكية؛ شفوية كانت أو فعلية، ويعدها هي فقط المادة الصحيحة. ويغالي هذا المنهج في الكيان الإثني أو العرقي ويعدّه هو المُكّون للإنسان.

وينقد المنهج الاجتماعي في دراسة الأديان، في تركيزه على الجماعة الاجتماعية، وفي النظر إلى الدين على أنه عامل بنَّاء أو هدَّام فحسب، مُوحِّد أو مُفِّرق يؤدي إلى إلى التكامل

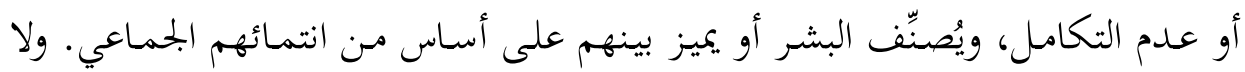
يعترف مثل المنهج الأنثربولوجي إلا بالمعلومات أو المواد السلوكية والعملية. وينقد المنهج

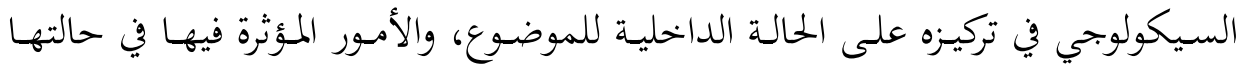
الذاتية. والدين عنده حالة شعورية تتأثر بوضعية الإنسان.

أما المنهج التاريخي فهو يهتم بالبحث في أنماط التغيير ويعتمد على العامل التطوري، ومهمة هذا المنهج الكشف عن المراحل التاريخية التي يمر بها الدين، والتطورات التي تصيبه 


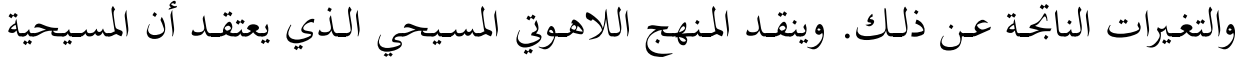

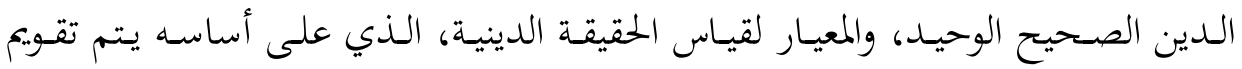

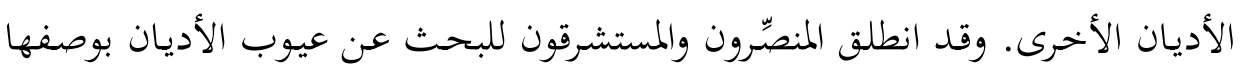

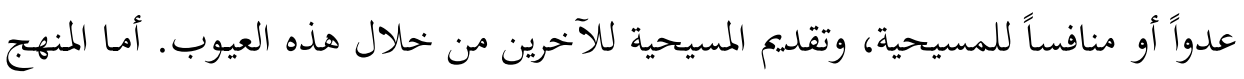

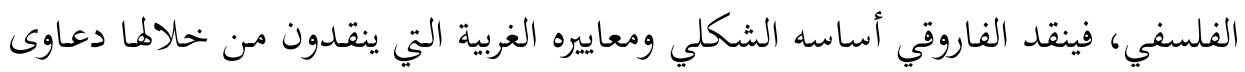

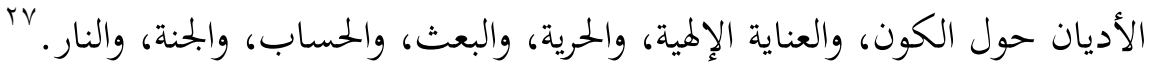
ولتجنب عيوب هذه المناهج، يؤكد الفاروقي أن فريقاً من علماء مقارنة الأديان بحثوا

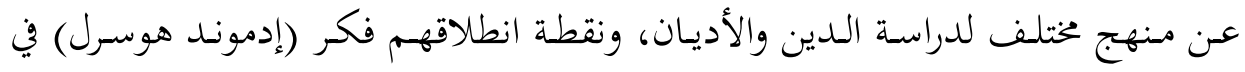

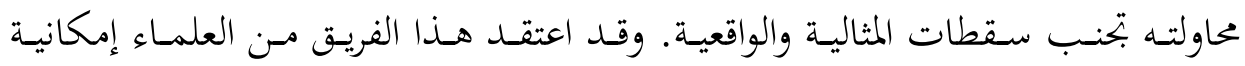

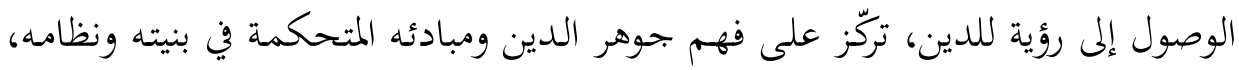
وذلك من خلال تعليق الأحكام المسبقة، والنظر إلى الظواهر الدينية كما هي، وترك هذره

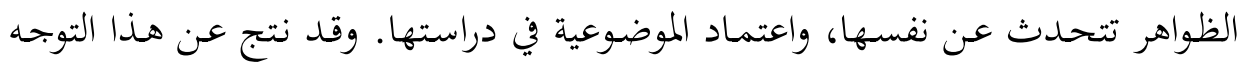

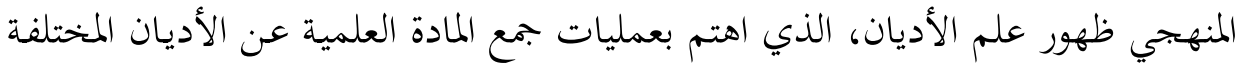

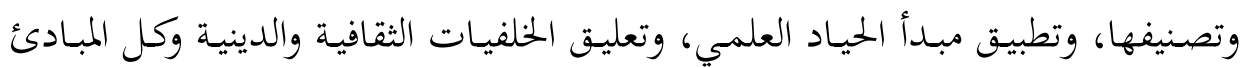

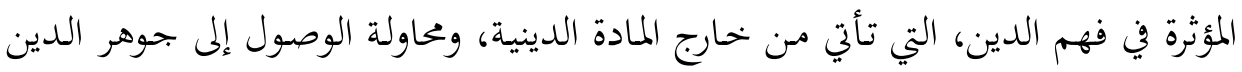

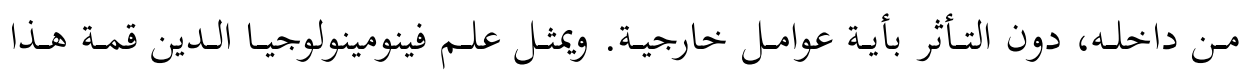

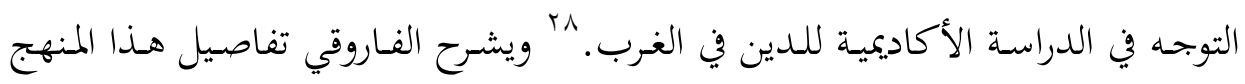

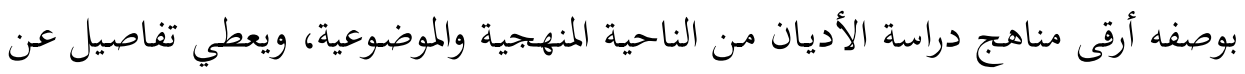

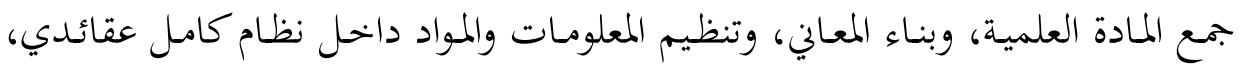
وطقوسي، ومؤسسي، وأخلاقي، وفني، وربط هذا كله بتاريخ الحضارة المعنية بوصفه كلّاً.

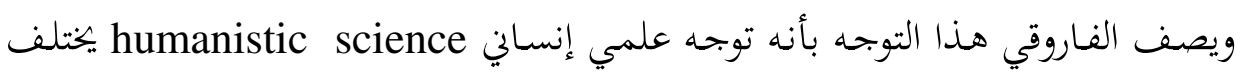
عن العلم الاجتماعي في تعامله مع المادة العلمية.

${ }^{27}$ Ibid, pp. 414-415.

${ }^{28}$ Ibid, p416.

${ }^{29}$ Ibid, p420. 


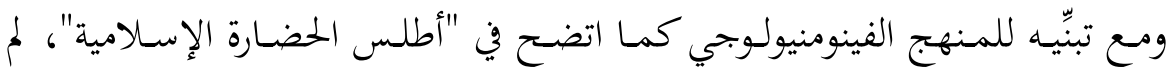

يسلم هذا المنهج من نقد الفـاروقي؛ إذ لم يقبل الفـاروقي أن يتنازل هذا المنهج عن مبدأ التقـويم، وذلك بـالنظر إلى ارتبـاط مـادة فينومنيولوجيـا الدين بقـيم ومعانٍ عالميـة يجـبـ ألّا يُكتفي بعرضها في شكل أبنيـة وجـواهر، ولكنها تحتـاج إلى تقوسم، وبخاصة على مستوى المقارنة بين الأديان. فهذه المادة الدينية ليست جامدة، ولا يمكن عزلها عن حياة البشر، ولـذلك يجـب على عـالم فينومنيولوجيـا الـدين أن يطوِر نظامـاً مـن المبـادئ المـاوراء دينيـة تحدث داخله عملية تقويم المعاني الكلية.

ويذكر الفـاروقي أنه على الرغم مـن وجـود عـدة ححاولات لاهوتيـة مسيحية للدراسة

المقارنـة للأديـان، فإنـه لا يوجــ حهتى الآن مـا يسميه الفـاروقي بـ: المـاوراء الـدين الناقــ Critical meta-religion الاختلافات بين الأديان تنتمي إلى السطح، بينما تشير وجحوه الاتفـاق العامة بين الأديان

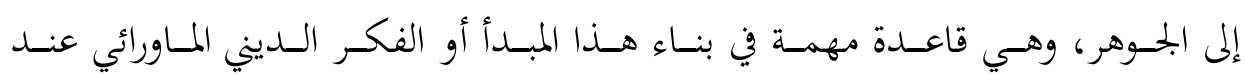

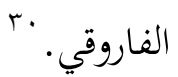

\section{رابعاً: نحو نظرية إسالامية في الدين الماورائي}

ويضع الفـاروقي نظريته الإسـلامية (فيما وراء الدين) داخل إطار أكبر وأثمل، وهـو الإطار العالمي؛ إذ يسعى إلى تطوير لاهوت عـالمي يصفه بأنه لاهوت ناقد، كما يتضح

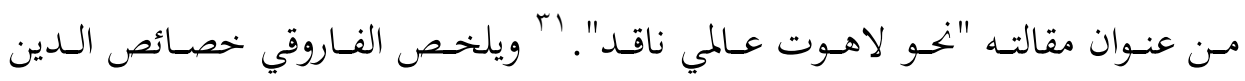
الماورائي meta-religion بحسب الإسالام، وهي خصائص عقلية وناقدة، فيما يلي: ا ـ أن الدين المـاورائي -بكسـب الإسـلام - لا يـفض أي ديـن مـن الأديـان، ويعطي لكل دين فائـدة الشـك وأكثر، ويفـترض أن كل دين مبني على أسـاس مـن وحي إلهي، ${ }^{30}$ Ibid., p. 424.

31 Al-Fārūqí, Isma'úl Rājí. "Towards a Critical World Theology" in Towards Islamization of Disciplines, The International Institute of Islamic Thought, Herndon, USA: 1416/1995, pp409-453. 
وأمر إلهي حستى يثبـت، وبـلا شـك في أن العناصـر المكونـة لهـذا الـدين هي مـن صـنع الإنسان.

r. أن الدين الماورائي -بحسب الإسلام- يربط أديان التاريخ بالمصدر الإلهي، على

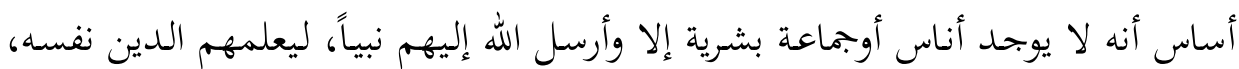

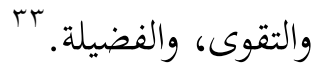

r. أن الدين الماورائي بحسب الإسلام يمنح الاعتماد أو الاعتراف لكل البشر في

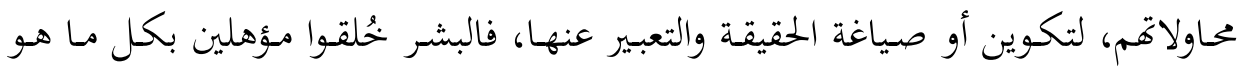

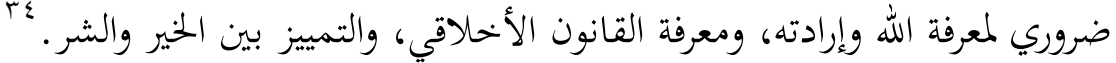
ع. إدراك العواطف والميول البشرية، وأشكال التعصب والتمييز وتأثيرها على مـا تمّ

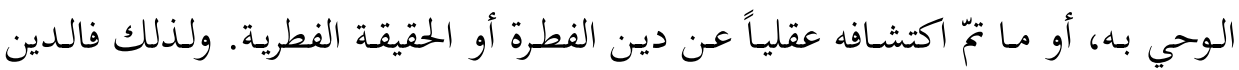

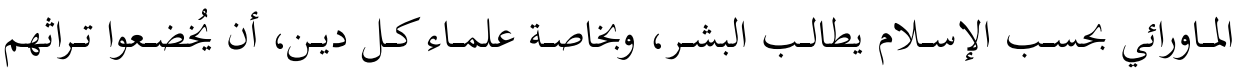
الديني للفحص العقلي والنقدي وللتمحيص، لكي يتخلصوا مسن كل العناصر التي تمّ التأكد من أها إضافات إنسانية وتعديلات وتزييفات. وفي هذه المهمة النقدية التاريخية

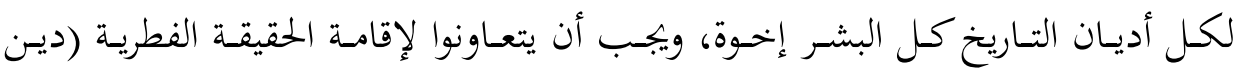
الفطرة) التي توجد في الأديان.

ه. يقدّر الدين الماورائي -بحسب الإسلام- العقل الإنساني، إلى حد جعله صنواً للوحي دون تناقض بينهما، ودون محاولة إزاحة كل منهما الآخر. ففي المنهجية الإسلامية

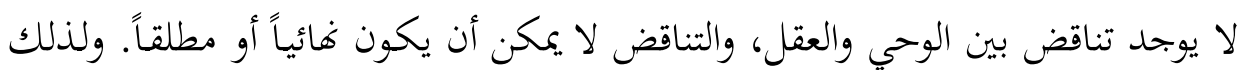
فعالم الدين المسلم متسامح دائماً، وخاضع للنقد ولضرورة إعطاء الدليل.

\footnotetext{
${ }^{32}$ Ibid., p. 449.

${ }^{33}$ Ibid., p. 449.

${ }^{34}$ Ibid., p. 449.

${ }^{35}$ Ibid., p. 450.
} 


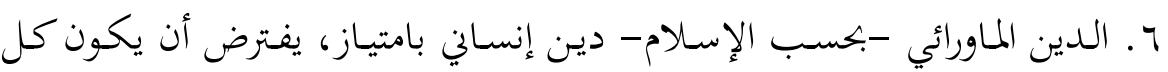

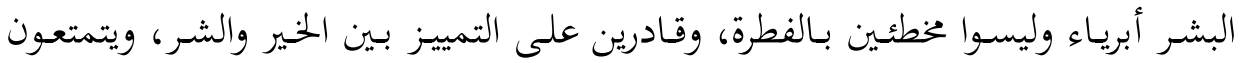

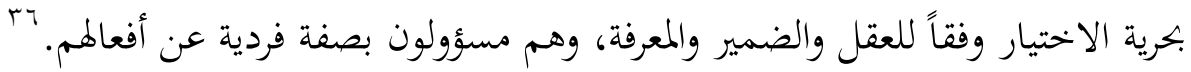
V. الدين الماورائي -بحسب الإسلام- دين يعترف بالحياة الدنيا ويقدرها، ويعترف

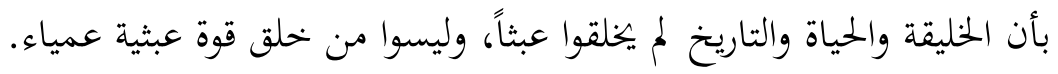

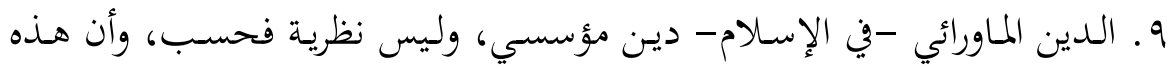

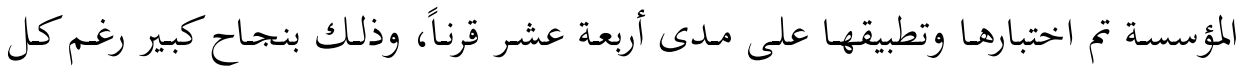

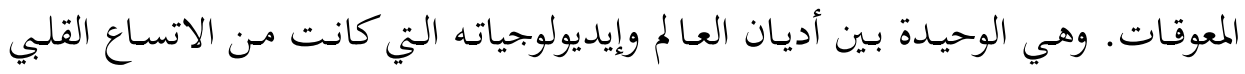

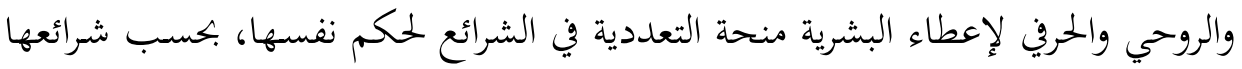

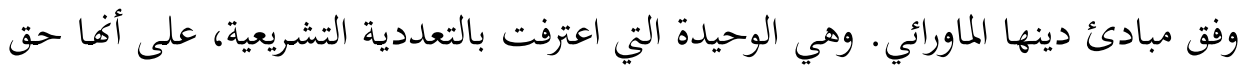

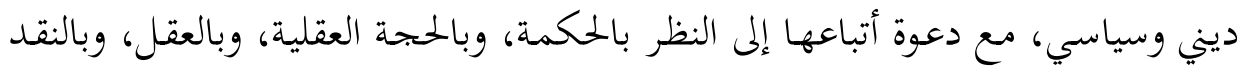

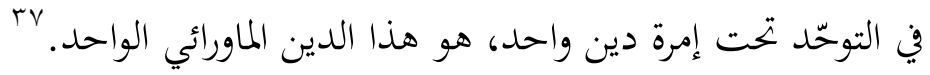
إن نظرية الدين الماورائي وفقاً للإسلام، بحسب تحليل الفاروقي، هي نظرية يحاول

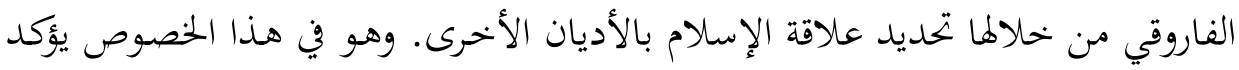

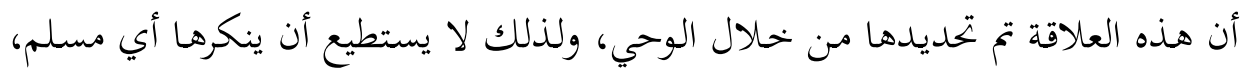

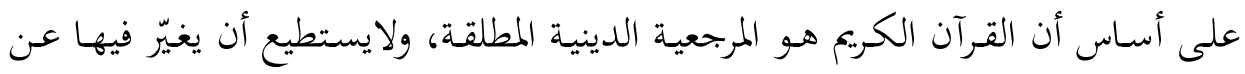

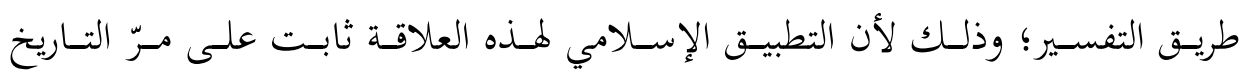

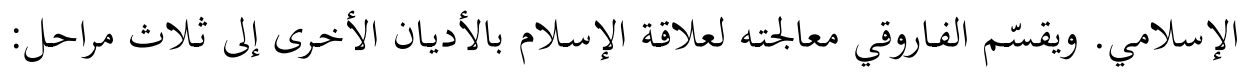

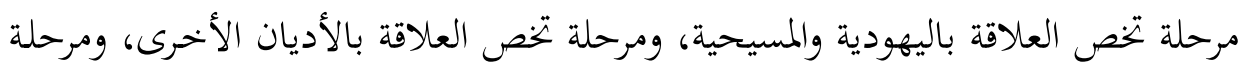
ثالثة تخص العلاقة بالبشر عامة، بصرف النظر عن تبعيتهم الدينية أو الأيديولوجية. وبالنسبة لليهودية والمسيحية فالإسلام يخصهما بعلاقة خاصة معترفاً بأفما ديانتان

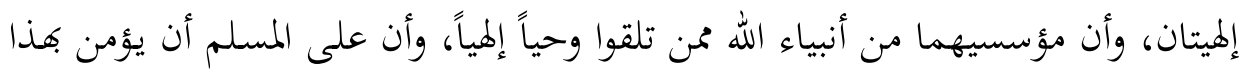

${ }^{36}$ Ibid., p. 450.

${ }^{37}$ Ibid., p. 450. 
بوصفه جزءاً من الإسلام، ومس الحقيقة الدينية. وبالإضـافة إلى الحنيفية فإن اليهودية،

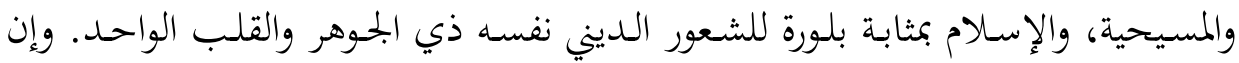

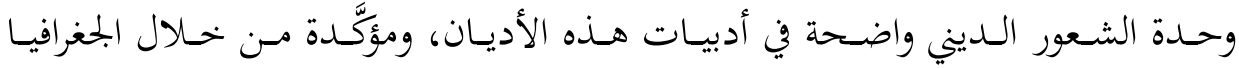

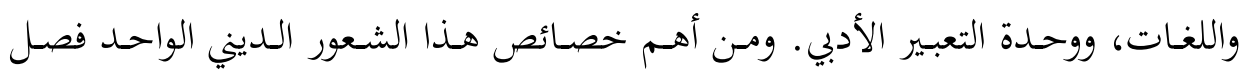

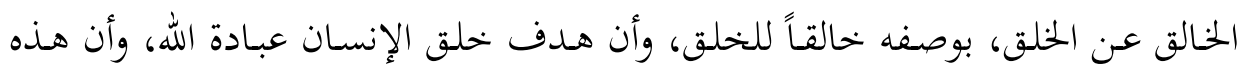

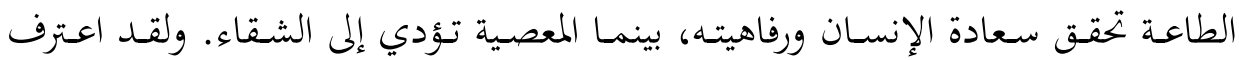

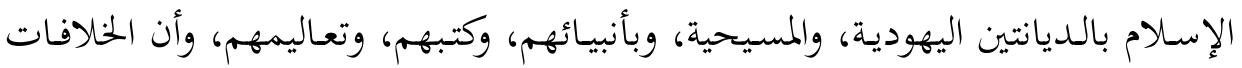

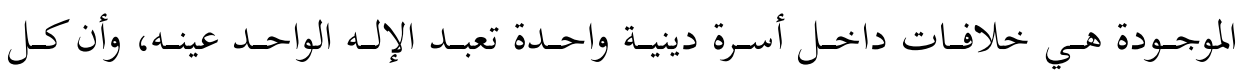
الاختلافات الثقافية، والاجتماعية، والسياسية، والاقتصادية تنتهي عند لاندا لا إله إلا الله.

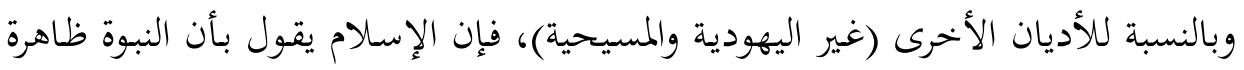
عالمية وقعت في كل الزمان والمكان، ورسالتها واحدة وهي عبادة الإله الواحد وفعل الخير.

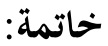

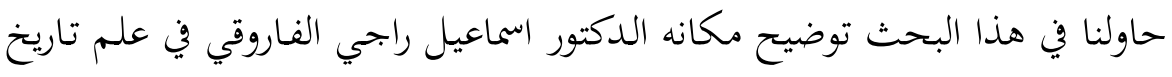

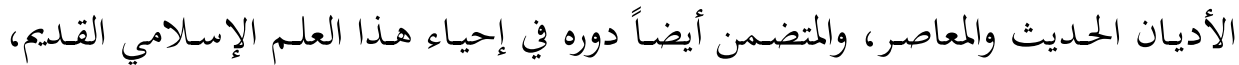

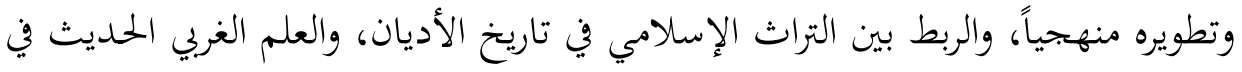

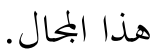

وقد بتلّت جهود الفاروقي في المساهمة في تطوير هذا العلم في الغرب بالمشاركة مع

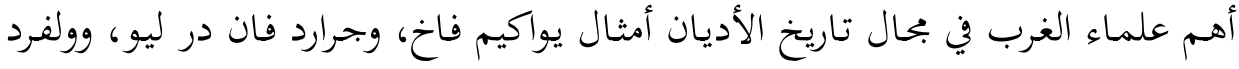

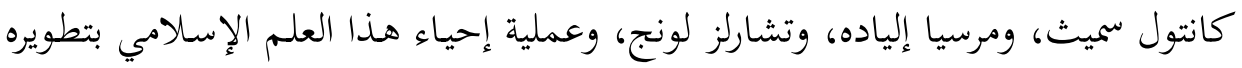

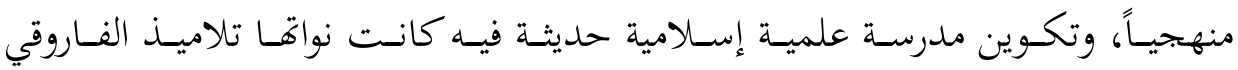

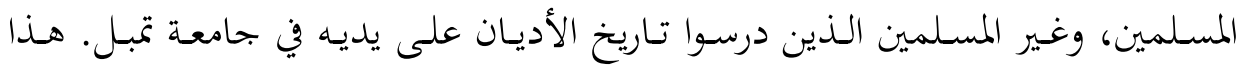

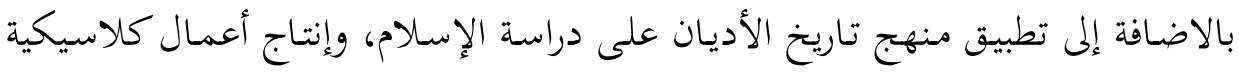


في هذا البحال، ومـن أهمها (أطلس الحضارة الإسلامية)، الذي طبق فيه الفـاروقي منهج تاريخ الأديان وفينومينولوجيا الدين على دراسة الإسلام.

ويمكـن القـول بأنـه إذاكـان الشـيخ الـدكتور محمـد عبـد الله دراز قـد افتتح الإسـهام الإسلامي الحديث في علم تاريخ الأديان بكتابه المشهور (الدين: بحوث ممهدة في تاريخ

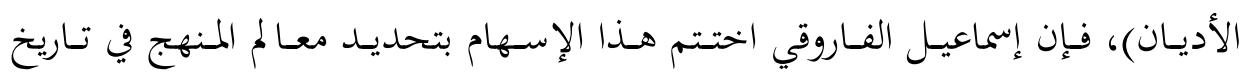
الأديان، وربطه بأحساث التطورات العلمية، وآخرها مـهنج مدرسة فينومينولوجيا الدين. وإذا كان كتاب الشيخ دراز قد وُصف بأنه تمهيد، فإن أطلس الحضارة الإسلامية يمثل

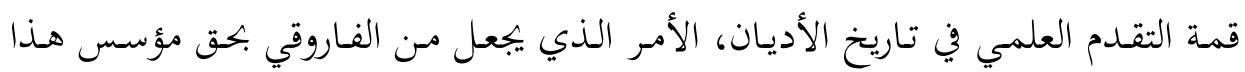

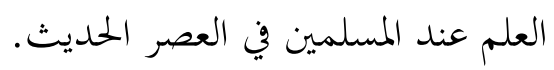

ونوصي في هاية هذه الدراسة بضرورة الاهتمام بنشر تراث الفاروقي في العالم العربي

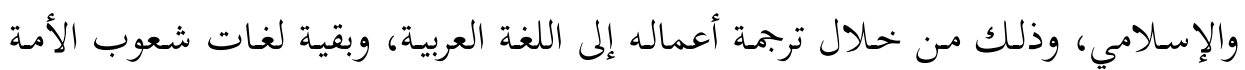

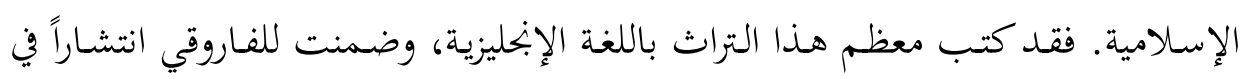

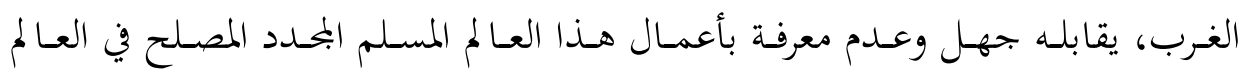
الإسلامي.

كما توصي هذه الدراسة أيضا بضرورة الاهتمام بعلم تاريخ الأديان، وربطه بتراث

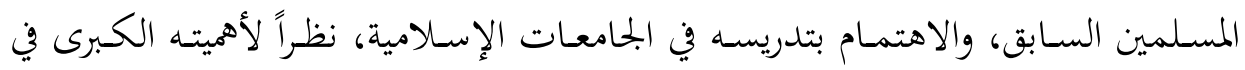

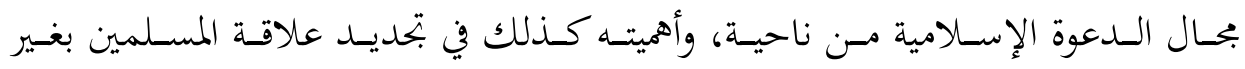
المسلمين، وفائدته الكبرى في تأهيل المسلمين في بحال حوار الأديان، وبناء الجسسور بين المسلمين، وغير المسلمين. 